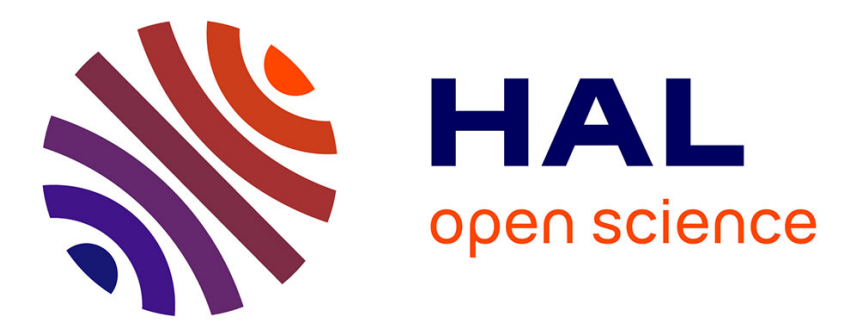

\title{
Biodiversity impact assessment of building's roofs based on Life Cycle Assessment methods
}

Aline Brachet, Nicoleta Schiopu, Philippe Clergeau

\section{To cite this version:}

Aline Brachet, Nicoleta Schiopu, Philippe Clergeau. Biodiversity impact assessment of building's roofs based on Life Cycle Assessment methods. Building and Environment, 2019, 158, pp.133-144. 10.1016/j.buildenv.2019.04.014 . mnhn-02568453

\section{HAL Id: mnhn-02568453}

\section{https://hal-mnhn.archives-ouvertes.fr/mnhn-02568453}

Submitted on 22 Oct 2021

HAL is a multi-disciplinary open access archive for the deposit and dissemination of scientific research documents, whether they are published or not. The documents may come from teaching and research institutions in France or abroad, or from public or private research centers.
L'archive ouverte pluridisciplinaire HAL, est destinée au dépôt et à la diffusion de documents scientifiques de niveau recherche, publiés ou non, émanant des établissements d'enseignement et de recherche français ou étrangers, des laboratoires publics ou privés.

\section{다)(1) $(5$}

Distributed under a Creative Commons Attribution - NonCommerciall 4.0 International 


\section{Biodiversity impact assessment of building's roofs based on Life Cycle Assessment} methods

BRACHET Aline ${ }^{1,2^{*}}$, SCHIOPU Nicoleta ${ }^{1}$, CLERGEAU Philippe ${ }^{2}$

\section{1,2"Aline BRACHET}

aline-brachet@hotmail.fr

Université Paris Est, Centre Scientifique et Technique du Bâtiment, 24 rue Joseph Fourier, 38400 Saint-Martin-d'Hères

Muséum National d'Histoire Naturelle, UMR CESCO MNHN/UPMC/CNRS, 43 rue Buffon, 75005 Paris, France

\section{'Nicoleta SCHIOPU}

nicoleta.schiopu@cstb.fr

Université Paris Est, Centre Scientifique et Technique du Bâtiment, 24 rue Joseph Fourier, 38400 Saint-Martin-d'Hères

2Philippe CLERGEAU

philippe.clergeau@mnhn.fr

Muséum National d'Histoire Naturelle, UMR CESCO MNHN/CNRS/Sorbonne Univ., 43 rue Buffon, 75005 Paris, France

Corresponding author:

E-mail address: aline-brachet@hotmail.fr (Aline BRACHET) 


\section{Abstract}

To fight against the biodiversity loss and to take advantage of ecosystem services that nature can offer, urban planners integrate green spaces in urban projects. However to assess green spaces, attention is generally paid to local biodiversity (i.e. "in situ") which concerns the plot on which buildings are constructed. The biodiversity impacted outside the construction site (i.e. "ex situ") which concerns the extraction of materials, transportation and waste, is rarely associated to the project assessment.

In this study, two endpoint Life Cycle Assessment (LCA) methods are applied: ReCiPe 2016 and Impact World + to assess a conventional roof and three different types of green roofs. As Life Cycle Inventory (LCI) data about urban plants are missing, we created new data to model the vegetation layer of green roofs by collecting information nearby plants nursery.

This work shows that 1) extensive green roof generates the least biodiversity loss, 2) "ex situ" biodiversity is 10 times more impacted than "in situ" biodiversity, 3) the impact of the vegetation layer on the biodiversity loss is significant.

LCA methods do not enable to cover all pressures threatening biodiversity and they also lack precision to assess "in situ" biodiversity. Nevertheless, their main strength is to consider "ex situ" biodiversity along the value chain of the studied systems.

Coupling LCA with ecological expertise should improve the assessment by taking into account local specificities and both negative and positive impacts of a system (e.g. "in situ" biodiversity gains with green roofs).

Keywords: Life Cycle Assessment, biodiversity, green roofs, urban plants Life Cycle Inventories 


\section{Introduction}

Many studies are pointing out that Earth is living its sixth mass extinction due to the global acceleration of the pace of species disappearance [1,2]. In the latest edition of the International Union for Conservation of Nature (IUCN) global Red List of Threatened Species, on the 91523 species studied, 25821 are classified as threatened: $41 \%$ of amphibians, $13 \%$ of birds and $25 \%$ of mammals [3]. In 2017 , Hallmann et al. have shown that in the last 27 years, between $76 \%$ and $82 \%$ of the airborne insect biomass has declined in nature protection areas in Germany [4]. In France, a third of the country's bird population has declined in 15 years [5]. According to the World Wildlife Fund (WWF), by 2020 and with the current biodiversity loss rate, the world will have witnessed a two-thirds decline in global wildlife populations in only half a century [6].

With the disappearance of a species, two phenomena can occur: another organism plays its functional role in nature or the functional role in nature is lost. The result can be a loss in the variety of life on our planet and it can also be a loss in the services associated with it and provided by nature to humans [7]. These biodiversity services are many and are classified into 4 groups [8] : supporting services (nutrient cycling, soil formation...), provisioning services (food, fresh water, fuel, materials...), regulating services (climate, flood and disease regulation, water depollution...) and cultural services (well-being, aestheticism, hobbies...). Losing those benefits could be dangerous for humans, especially in cities where more and more people are exposed to environmental issues.

From this statement, governments started to consider biodiversity conservation as a major environmental issue [9], as climate change or energy consumption. Therefore, in October 2010, the Convention on Biological Diversity (CBD) in cooperation with the United Nations Environment Program (UNEP) created the new "Strategic Plan for Biodiversity 2011-2020". It establishes the international and general framework for the strategy and actions for biodiversity. The plan contains 5 major goals known as "Aichi Biodiversity Targets" [10] : 
- Goal A: Address the underlying causes of biodiversity loss by mainstreaming biodiversity across government and society

- Goal B: Reduce the direct pressures on biodiversity and promote sustainable use

- Goal C: Improve the status of biodiversity by safeguarding ecosystems, species and genetic diversity

- Goal D: Enhance the benefits to all from biodiversity and ecosystem services

- Goal E: Enhance the implementation through participatory planning, knowledge management and capacity building.

For now, none of those goals have been reached [10]. However, five pressures on biodiversity have been clearly identified by the Millennium Ecosystem Assessment (MEA) report [8]: habitat change, invasive species, over-exploitation of resources, pollution, and climate change. All of those pressures are mainly caused by human activities $[8,11]$. The international trade in our globalized economy also accounts for a significant share of biodiversity threats $[12,13]$. Even if there is an increasing demand for environmental information on products and services provided in the global market [14], consumers and policy makers are still often unaware of the biodiversity impacts "hidden" in imported products. Nevertheless, many international declarations and studies have built a strong case for protecting global and local biodiversity (e.g. MEA [8], The Economics of Ecosystems and Biodiversity (TEEB) [15]) [16]. Taking into account not only local, but also global impacts, is the first step toward more sustainable consumption patterns and for reducing rates of global biodiversity loss [17]. In addition to the difficulties to evaluate indirect impacts, quantifying them is also a main challenge. The assessment of the global impacts tied to anthropic activities is essential to target coherent and effective actions for reducing human pressure on biodiversity [18].

In this context, increasing attention is being given to Life Cycle Assessment (LCA) as a decision support tool $[19,20]$. Since 2003 , LCA has been recognized by the European 
Commission as the best tool to assess the environmental performance of products [21]. It is a well-established methodology defined in ISO standards (ISO 14040 [22] and ISO 14044 [23]), able to capture direct and indirect environmental impacts of human activities and the complexity of their interactions $[17,24]$. LCA methodology quantifies the environmental impacts of a product along its entire life cycle (from raw material extraction to consumer use and product disposal) $[17,25]$. It enables the identification of hotspots in environmental impacts associated with the entire value chains of the product [17]. The aim is to select products or services with lower environmental impacts, compared on a functional basis [26]. The Technical Committee of European Committee for Standardization 350 (CEN TC 350) has developed European standards to assess the sustainability of construction works, for example, EN 15804 (for construction products) [27] and EN 15978 (for buildings) [28]. These standards enable to calculate presently seven environmental impact's indicators [29]: depletion of abiotic resources-elements, depletion of abiotic resources-fossil fuels, acidification of soil and water, ozone depletion, global warming, eutrophication, and photochemical ozone creation. CEN TC 350 is discussing the possibility of adding biodiversity as a new environmental impact category in European standards [30].

Many biodiversity assessment models have been developed over the last two decades: Ecoindicator 99 [31], ReCiPe (endpoint) [32], Impact 2002 + [33], Impact World + [34], LC Impact $[14,35] \ldots$ Presently, European standards do not recommend any methodology to assess biodiversity loss with a LCA approach. Nevertheless, work is in progress on this issue [30] as LCA seems to meet all the criteria for an appropriate biodiversity evaluation: interdisciplinary, inclusivity, comprehensibility and reproducibility [36]. Indeed, LCA is a multi-criteria analysis, it respects the specificity of biodiversity while maintaining methodological accuracy, it includes the impacts on the biodiversity "in situ" related to the products considered (i.e. direct effects) and on the biodiversity "ex situ" (i.e. indirect effects). Finally, LCA is an easily replicable methodology when the framework is well defined. However, as Curran suggests in 2011, it is important to see "if they are reflecting 1) the major drivers of biodiversity loss as identified by the MEA (i.e. the 5 pressures) and 2) whether they capture the concept of 
biodiversity adequately both in its inherent variation and its non-uniform distribution across the planet" [37].

LCA methods that calculates a biodiversity damage has never been applied to the urban context. The aim of this study is to fill this gap by assessing the biodiversity impacts of four roof systems used for buildings with two recent LCA methodologies (ReCiPe 2016 [32] and Impact World + [34]): 1) a conventional roof, 2) an extensive green roof, 3) a semi-intensive green roof and 4) an intensive green roof. This will enable to identify the roof system that causes the lowest biodiversity loss. Results and calculation models of selected methods will be then put in perspective regarding to the ecological expertise studies for green roof and regarding to the prescription mentioned above (i.e. the evaluation has to take into account the 5 pressures on biodiversity [8] and the local specificities $[37,38])$ in order to check their robustness.

Green roofs they are increasingly promoted by public authorities and policies for their projects [39]. Many researches as reviewed by Shafique et al. (2018), showed that green roofs are the best management practices due to social, environmental and economic benefits [40]. Although green roofs can induce higher construction and maintenance costs in comparison with conventional roofs depending on many factors [41] (e.g. materials used, location, green roof type, plants chosen...), green roofs can also save energy $[42,43]$, enhance storm water management, reduce urban noise, remove pollution from the air, have an effect on urban heat island and on human health, and, finally preserve biodiversity [40]. Those socio-environmental aspects are difficult to evaluate in terms of potential financial gain. However, some studies estimate that the reduction of energy used can go up to $6 \%$ in summer [44]) and Teotonio et al. quantify benefits costs at 71 and 506 euros $/ \mathrm{m}^{2}$ for extensive and intensive green roofs respectively [45].

Considering both installation costs and benefit costs, green roofs can finally be less expensive than traditional roof [46] and thus public policies encourage green roofs installation as a response to cities' environmental issues, including biodiversity conservation 
[47]. Many countries like France, USA, Japan, Germany are adopting green roofs application [40]. For example, in France, commercial buildings with a sales area larger than $1000 \mathrm{~m}^{2}$ must green up their rooftops $[48,49]$.

This study owes its originality to the calculation of the overall impacts of roof systems on biodiversity, with a focus on the vegetal layer. Indeed, green roofs are well studied in the literature (Saïz et al. [44], Lamnatou \& al. [50], Chenani et al. [51], Gargari et al. [52], Vacek et al. [53]...), nevertheless, the vegetal part is either omitted or not taken into account entirely because of a lack of LCA data. Indeed, in well-known LCA databases such as Ecolnvent 3 [54], Agri-footprint [55], Swiss Input-Output Database [56], etc. data about urban plants are missing. To our knowledge, presently in the literature the only available data on urban plants concern one type of shrub/bush, supplied by the AGRIBALYSE 1.3. database [57]. The AGRIBALYSE was launched by the French Environment and Energy Management Agency (ADEME) to fill the lack of Life Cycle Inventories (LCI) data for the agricultural products.

Thus, this work enables to create inventory data for green roof plants to consider their life cycle too, as well as any other roof components (concrete, plastics...).

\section{Materials and Methods}

The goal of this study is to compare the biodiversity impacts of 4 fictive flat roof systems (slopes < 5\%) located in France: one conventional roof and three green roofs (extensive, semi-intensive and intensive green roofs).

When realizing a LCA it is possible to discern direct and indirect impacts. In this study, direct impacts refer to the biodiversity affected on the construction site, or on the "in situ" biodiversity. Indirect impacts refer to the biodiversity affected outside the construction site, or on the "ex situ" biodiversity (e.g. the biodiversity that is affected on the material extraction quarry or during the material transportation).

In this study, roofs impact is first assed for the "ex situ" biodiversity and then for the "in situ the biodiversity. It has been conducted according to ISO standards 14040 and 14044 [22,23] 
stages: 1) goal and scope, 2) life cycle inventory, 3) life cycle impact assessment, and 4) interpretation.

\subsection{Goal and scope}

The conventional roof is modeled according to a roof from the PEBIOS (Environmental Performance of Biobased Buildings) project [58] with 5 different layers (Figure 1.a.): 1) a concrete slab, 2) a vapor barrier, 3) an insulation, 4) a sealing membrane and 5) gravels. The green roofs are modeled according to Chenani et al. [51] with 8 layers (Figure 1.b.): 1) a concrete slab, 2) a protection layer, 3) a root barrier, 4) a drainage layer, 5) a filter layer, 6) a water retention system, 7) a substrate and 8) a vegetation layer.

a)

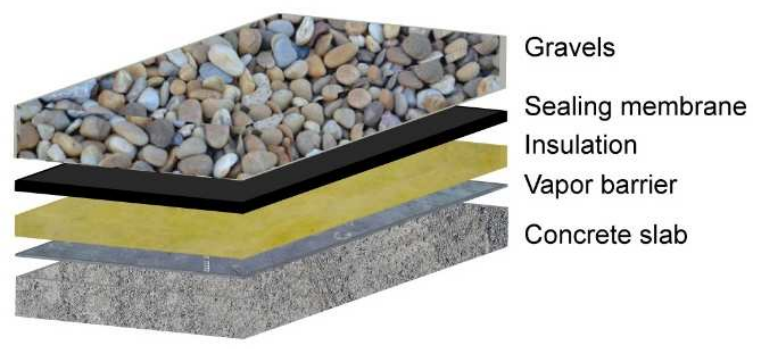

b)

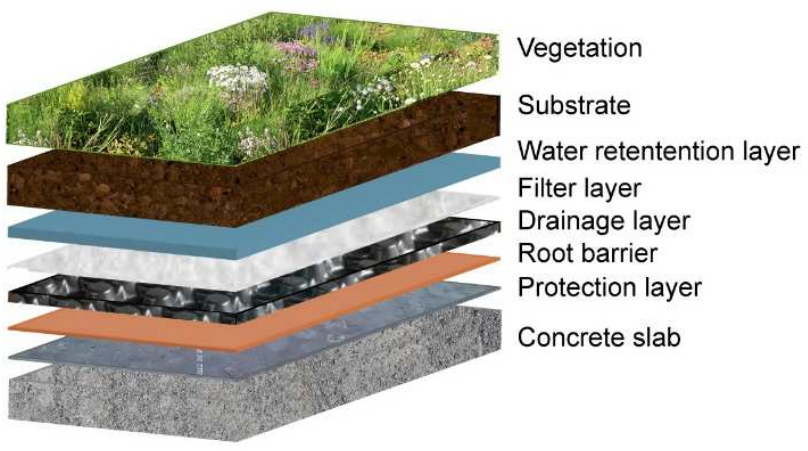

Figure 1: Layers modeled for a) the conventional roof and b) the green roofs

The functional unit is $1 \mathrm{~m}^{2}$ of roof with a lifespan of 40 years (the membrane lifespan of a green roof $[51,59])$. It is a cradle to grave LCA and it includes the 4 major stages of the life cycle: product, construction process, use and end of life. In order to be consistent with the building's European standard (EN 15 978) [28], the systems were modeled with 16 modules as shown in Figure 2. 


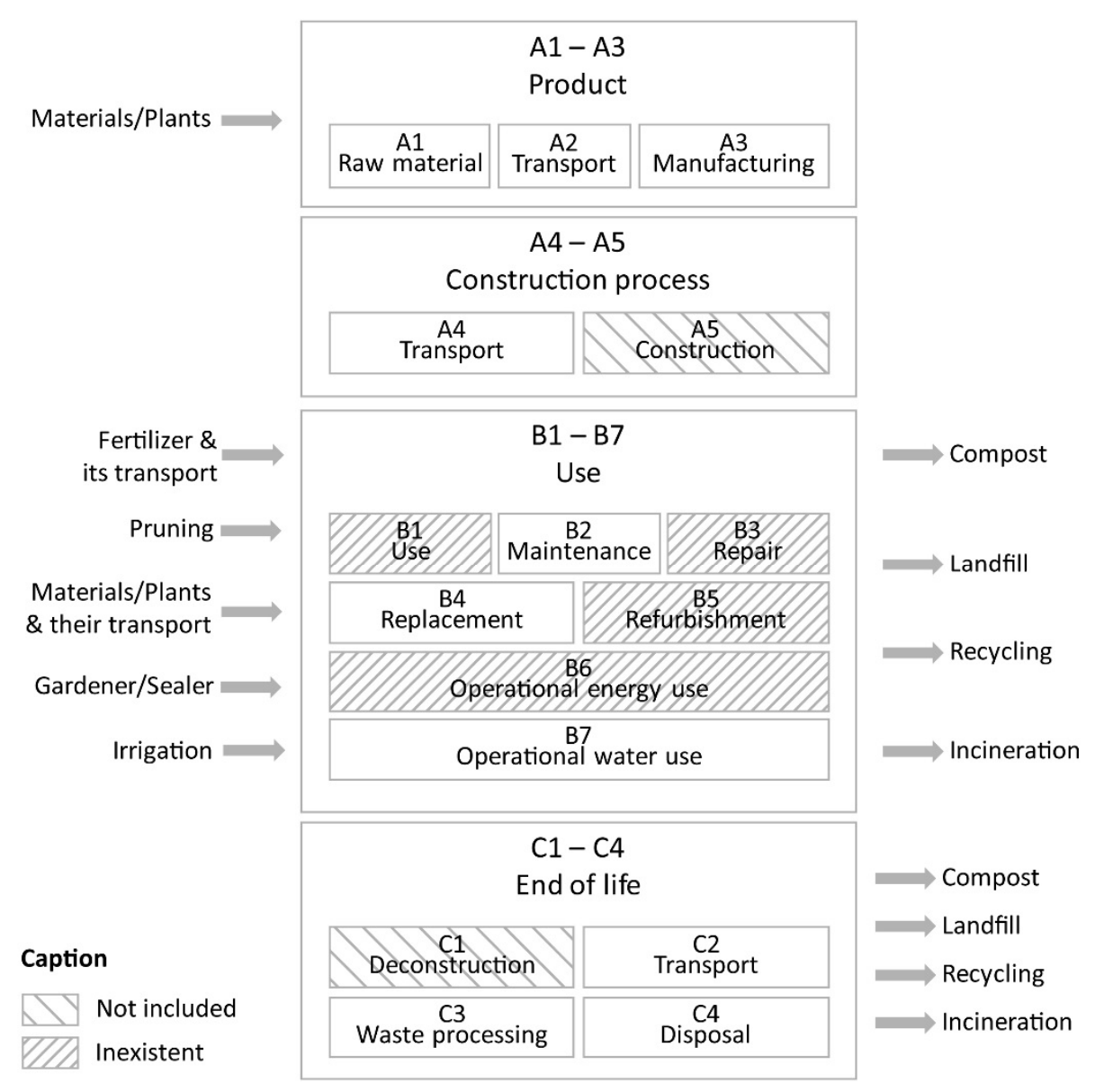

Figure 2: System boundaries according to the different stages of the building assessment of the European standard EN 15978 [28], not shown: input/output related to background processes.

\subsection{Life cycle inventory}

\subsection{1. $\mathrm{LCl}$ for the "ex situ" biodiversity impact assessment}

Components and processes included in the 4 roofs systems were modeled based on data from the PEBIOS project [58] for the conventional roof and the works of Kosareo and Ries, (2006) [59], Chenani et al. (2015) [51], Vacek et al. [53], Lamnatou and Chemisana [50], [53] for the green roofs.

The Ecolnvent 3.4. [54] (Ecolnvent 3 - allocation, cut-off by classification - Unit) and the AGRIBALYSE 1.3. database [57] enabled the modeling of all roofs materials except the urban plants used onto green roofs. Therefore, new plants data specifically used on green roofs are developed during this work. 


\subsubsection{Product stage (A1 to A3)}

Table 1 and Table 2 present the materials and the quantities used to model the conventional roof and the three green roofs.

Table 1: Conventional roof materials (1 $\left.\mathrm{m}^{2}\right)$. Data from Ecolnvent 3.4.

\begin{tabular}{|l|l|l|l|}
\hline Layer & Material & Mass [kg] & Thickness [mm] \\
\hline Concrete slab & Concrete & 488.5 & 200 \\
\hline Vapor barrier & Polyethylene High Density (HDPE) & 1.41 & 1.5 \\
\hline Insulation & Stone Wool & 20.8 & 260 \\
\hline \multirow{2}{*}{ Sealing } & Polyvinylchloride & 1 & 0.8 \\
\cline { 2 - 4 } & Asphalt & 75 & 30 \\
\hline Gravel & Gravel & 360 & 200 \\
\hline Total & & 946.71 & 692.3 \\
\hline
\end{tabular}

Table 2: Green roofs materials (1 $\left.\mathrm{m}^{2}\right)$. Data from: ${ }^{1}$ Ecolnvent 3.4., ${ }^{2}$ AGRIBAL YSE 1.3., ${ }^{3}$ Created.

\begin{tabular}{|c|c|c|c|c|c|c|c|}
\hline \multirow{2}{*}{ Layer } & \multirow{2}{*}{ Material } & \multicolumn{2}{|c|}{$\begin{array}{l}\text { Extensive green } \\
\text { roof }\end{array}$} & \multicolumn{2}{|c|}{$\begin{array}{l}\text { Semi-intensive green } \\
\text { roof }\end{array}$} & \multicolumn{2}{|c|}{ Intensive green roof } \\
\hline & & $\begin{array}{l}\text { Mass } \\
{[\mathrm{kg}]}\end{array}$ & $\begin{array}{l}\text { Thickness } \\
{[\mathrm{mm}]}\end{array}$ & $\begin{array}{l}\text { Mass } \\
{[\mathrm{kg}]}\end{array}$ & $\begin{array}{l}\text { Thickness } \\
{[\mathrm{mm}]}\end{array}$ & $\begin{array}{l}\text { Mass } \\
{[\mathrm{kg}]}\end{array}$ & $\begin{array}{l}\text { Thickness } \\
{[\mathrm{mm}]}\end{array}$ \\
\hline $\begin{array}{l}\text { Concrete } \\
\text { slab }\end{array}$ & Concrete $^{1}$ & 488.5 & 200 & 608.5 & 250 & 728.5 & 300 \\
\hline Protection & Polypropylene $^{1}$ & 0.3 & 1.8 & 0.3 & 1.8 & 0.3 & 1.8 \\
\hline $\begin{array}{l}\text { Root } \\
\text { Barrier }\end{array}$ & Polyethylene ${ }^{1}$ & 0.8 & 0.4 & 0.8 & 0.4 & 0.8 & 0.4 \\
\hline Drainage & $\begin{array}{l}\text { Polystyrene } \\
\text { foam slab }{ }^{1}\end{array}$ & 1.3 & 25 & 1.3 & 25 & 1.3 & 25 \\
\hline Filter & Polypropylene $^{1}$ & 0.15 & 1.9 & 0.15 & 1.9 & 0.15 & 1.9 \\
\hline $\begin{array}{l}\text { Water } \\
\text { retention }\end{array}$ & $\begin{array}{l}\text { Rock wool } \\
\text { (Grodan) }^{2}\end{array}$ & 4.8 & 40 & 7.2 & 60 & 9.6 & 80 \\
\hline
\end{tabular}




\begin{tabular}{|c|c|c|c|c|c|c|c|}
\hline \multirow{3}{*}{ Substrate } & Expanded clay ${ }^{1}$ & 10 & \multirow{3}{*}{100} & 20 & \multirow{3}{*}{200} & 30 & \multirow{3}{*}{300} \\
\hline & Crushed brick $^{1}$ & 10 & & 20 & & 30 & \\
\hline & Compost $^{2}$ & 80 & & 160 & & 240 & \\
\hline \multirow{4}{*}{ Vegetation } & Sedum $^{3}$ & 5 & \multirow{4}{*}{ - } & - & \multirow{4}{*}{ - } & - & \multirow{4}{*}{ - } \\
\hline & Grass seeds $^{1}$ & - & & 0.03 & & 0.03 & \\
\hline & $\begin{array}{l}\text { Centaurea } \\
\text { Montana }^{3}\end{array}$ & - & & 4.5 & & 1.5 & \\
\hline & Shrubs ${ }^{2,3}$ & - & & - & & 4 & \\
\hline \multicolumn{2}{|l|}{ Total } & 600.85 & $\begin{array}{l}369.1 \\
\text { (without } \\
\text { plants) }\end{array}$ & 822.78 & $\begin{array}{l}539.1 \\
\text { (without } \\
\text { plants) }\end{array}$ & 1046.2 & $\begin{array}{l}709.1 \\
\text { (without } \\
\text { plants) }\end{array}$ \\
\hline
\end{tabular}

All green roofs are modeled in the same way for: the protective layer, the root barrier, the drainage layer and the filtering layer. The substrate layer, the water retention system and the vegetation layer vary according to the type of green roof considered [60]. This leads to a variation of load and so, a change in the lift of the concrete slab.

\section{$\underline{\text { The substrate layer }}$}

The substrate thickness determines the vegetation types of the roof. Plants with a strong root development (i.e. shrubs, little trees) require a thicker substrate layer than plants with a small root development (i.e. moss or sedum) [41]. According to the French professional rules for green roofs [60], substrate deepness varies from 4 to $12 \mathrm{~cm}$ for extensive green roof (moss, sedum), 13 to $30 \mathrm{~cm}$ for semi-intensive green roof (grass and herbaceous plants, coppices) and more than $30 \mathrm{~cm}$ for intensive green roof (shrubs, lawn, small trees). A substrate layer of $10 \mathrm{~cm}$ has been considered for the extensive green roof, $20 \mathrm{~cm}$ for the semi-intensive green roof and $30 \mathrm{~cm}$ for the intensive one.

Chenani et al. (2015) [51] considered that $10 \mathrm{~cm}$ of substrate is equivalent to $100 \mathrm{~kg}$ of materials (10 kg of expanded clay, $10 \mathrm{~kg}$ of compost and $80 \mathrm{~kg}$ of crushed brick). A linear 
relationship between weight and thickness is assumed, which implies $200 \mathrm{~kg}$ of materials for the semi-intensive green roof and $300 \mathrm{~kg}$ for the intensive green roof.

\section{The water retention layer}

The water retention layer thickness (i.e. the water holding capacity) depends on the plant's water requirements, which are different regarding the green roof system [51]. Therefore, in this study, the thickness of the water retention layer follows the increase of the plant's water requirement: $4 \mathrm{~cm}$ for the extensive green roof which had a low water requirement [51], $6 \mathrm{~cm}$ for the semi-intensive green roof and $10 \mathrm{~cm}$ for the intensive green roof.

\section{$\underline{\text { The vegetation layer }}$}

In Ecolnvent 3.4., data about urban plants are missing and in AGRIBALYSE 1.3. there is only one horticultural data interesting for this study: a shrub.

To correctly take into account all of the green roof layers, we created the $\mathrm{LCl}$ of plants used in an urban context (green roofs, green facades and parks) by collecting data from "cradle to gate" corresponding to their technological itinerary: water, fertilizers and gasoline needs; culture duration, area and land occupation; labor; bucket; transport distances for the different components and waste production and management.

Complementary to the literature review, specific data were collected from two French plants nursery specialized in urban plants: nursery $A$ and $B$.

In the nursery A, data concern a variety of three sedums (Sedum Muralis, Sedum Spectabilis and Sedum Acre) and one herbaceous (Centaurea montana) classically used on roof plantation in the Rhônes-Alpes region (hot and dry summer, cold and wet winter). In nursery B, data concern a mix of several sedums (e.g. acre, album, lydium, sexangulare, floriferum, spurium, reflexum, pachyclados et lemon ball....) and a mix of shrubs (e.g. Lavandula angustifolia, Thymus pseudolanginosus, Abelia grandiflora, Erica cinerea, Santolina chamaecyparissus, Cistus pulverulentus, Lonicera Ophelie...). 
In this study, the extensive green roof is modeled with the mix of sedums coming from nursery $\mathrm{B}$ : one box of $1 \mathrm{~m}^{2}$ of sedum weighing $5 \mathrm{~kg}$ with breeding ground). The semiintensive green roof is modeled with herbaceous plants: Centaurea montana (nursery A) (9 pots $/ \mathrm{m}^{2}$ of $\left.0.5 \mathrm{~kg}\right)$ and grass $\left(0.05 \mathrm{~kg}\right.$ of grass seeds to cover of $1 \mathrm{~m}^{2}$ [61]). The intensive green roof is modeled with herbaceous plants ( 3 pots of Centaurea montana $+0.03 \mathrm{~kg}$ of grass) and 2 potted shrubs (2 $\mathrm{kg}$ each with the breeding ground), one from AGRIBALYSE and one from nursery $B$.

\section{The concrete slab}

The thickness of the slab is identical for the conventional roof and the extensive green roof (i.e. $20 \mathrm{~cm}$ ). Indeed, there is no need to resize the slab to support the additional layers required for an extensive green roof. However, for semi-intensive and intensive roofs, the weight due to the additional layers cannot be supported by the slab [62]. Its thickness has been increased by $5 \mathrm{~cm}$ and $10 \mathrm{~cm}$ respectively for the semi-intensive and for the intensive green roof.

\subsubsection{Construction process stage (A4 to A5)}

In this study, module A4 (transport of products) refers to the transport from the roof company to the construction site. We assumed that the construction company is a local one $(25 \mathrm{~km}$ between the two sites) and use a 3.5-7.5 metric ton lorry.

According to Vacek et al. [53], module A5 (construction) has a low environmental impact and was therefore omitted in this study.

\subsubsection{Use stage (B1 to B6)}

The main contributors during the use stage are the roofs maintenance (cleaning and plant needs), the components replacement (sealing, plants, substrate) and the irrigation. These contributors are taken into account via modules B2 (maintenance of the roofs), B4 
(replacement of products) and B7 (operational water use). Replace materials transportation and their end of life are considered in module B4 (replacement of products). Other contributors' impacts (modules B1, B3, B5 and B6) are inexistent at the roof scale and thereby are neglected [53].

The vapor barrier of the conventional roof has a lifespan of 20 years. This means that it is replaced one time during the lifespan of the roof. However, the protection layer of green roofs is not replaced because greening a roof can extend the service life of a membrane by two or three times [63].

For all the green roofs, the substrate erosion due to the wind and plants replacement is considered. In 40 years, according to nursery and landscape designer, we assumed that $1 / 4$ of the initial amount of substrate is eroded (i.e. $25 \mathrm{~kg}$ for the extensive green roof, $50 \mathrm{~kg}$ for the semi-intensive one and $75 \mathrm{~kg}$ for the intensive one) and that the entire vegetation is replaced once (i.e. $1.5 \mathrm{~kg}$ of sedum for the extensive green roof, $3.05 \mathrm{~kg}$ of herbaceous for the semi-intensive green roof and $7 \mathrm{~kg}$ of herbaceous + shrubs for the intensive green roof). For fertilization, we followed the recommendation of Vacek et al. [53]: $5 \mathrm{~g} / \mathrm{m}^{2}$ twice a year with a NPK ratio of 19:6:12 in spring and 10:9:19 in autumn. Green roofs are fertilized during the 4 first years, the time needed to set up a stable system (information provided by French's green roofs professionals).

For irrigation (module B7), plants water requirement is based on the Van Mechelen et al. [64] study which reviews green roofs water requirement for several climatic contexts.

Fertilization and irrigation occur only on the semi-intensive and the intensive green roof. Extensive green roofs don't need special care since sedum plants are very resistant to drought [62].

We modeled the plants pruning considering that every two years, $40 \%$ of the plant's weight is removed. 
We finally modeled the transport of the professional sealing or gardener in the module B2 (maintenance): 1 time/year for the conventional roof, 2 times/year for the extensive green roof, 4 times/year for the semi-intensive green roof and 12 times/year for the intensive green roof (information provided by French's green roofs professionals)

\subsubsection{End of life stage (C1 to C4)}

At the end of life of roofs, type and mass of components are assumed identical to the product stage $(A 1-A 2)$.

Wastes can have different scenario for their disposal, depending on their type (i.e. plastic, mineral or vegetation waste). According to Plastics Europe 2017 [65], plastic wastes are incinerated at $42 \%$, recycled at $31 \%$ and landfilled at $27 \%$. According to the National Union of Quarry Industries and Building materials (UNICEM) [66], mineral wastes are recycled at 65 $\%$ and landfilled at $35 \%$. We assumed that vegetation is entirely composted.

Wastes transportation distances to landfill or incineration plants refer to the Ecolnvent recommendations [67]: $77 \mathrm{~km}$ for non-hazardous wastes from construction site to landfill or incinerator. For the recycling center and the compost site, we assumed that they are in the same neighborhoods as the construction site and chose a distance of respectively $50 \mathrm{~km}$ and $0.5 \mathrm{~km}$

\subsubsection{LCl for the "in situ" biodiversity impact assessment}

Using LCA methods, the only option to assess the "in situ" biodiversity impact is to consider the land occupation through the land use indicator.

This study considers the $1 \mathrm{~m}^{2}$ of "in situ" occupation, during 40 years, links to the four roofs. Depending on the method, the land use indicator is not considering the same substances (occupation types). Concerning the urban area, some methods (e.g. ReCiPe 2016) differentiate four types of occupation (i.e. urban, urban continuously built, urban discontinuously built, urban green areas) whereas some others (e.g. Impact World +) only 
proposes one (i.e. urban discontinuously built). Also, LCA methods offer the possibility to consider the construction site occupation. For each roof, we assumed that construction and deconstruction states last one year, and that the urban occupation lasts 39 years.

This study does not take into account the "in situ" impact links to the transformation of a plot from one occupation to another.

\subsection{Life cycle impact assessment (LCIA)}

The LCA software tool used for this analysis is Simapro 8.5. Simapro is a process flow modeling program designed to help the user perform LCA under the guidelines provided in the ISO 14040 series [59]. In this study, calculation methods recommended by the EN 15978 to evaluate building's performance are not used because they do not make possible the biodiversity impact evaluation.

Since the 2000s, many endpoint methods have been developed (Table 3). To define the most pertinent method for this study, we evaluated them with 5 criteria: 1) the year of the last update, 2) the number of substances covered, 3) the method main strength, 4) its weakness and 5) the method availability in Simapro 8.5.

Table 3: Criteria to select the LCA methods. References : ${ }^{1}$ CEN TC 350 [30], ${ }^{2}$ EC-JRC [68], ${ }^{3}$ Simapro 8.4., 4 Chaudary \& al. 2015 [69], ${ }^{5}$ Impact World + [70], ${ }^{6}$ UNEP-SETAC [71], ${ }^{7}$ Allacker \& al. [72]

\begin{tabular}{|c|c|c|c|c|c|c|}
\hline Methods & $\begin{array}{l}\text { Last } \\
\text { update }\end{array}$ & $\begin{array}{l}\text { Amounto } \\
f \\
\text { substanc } \\
\text { es } \\
\text { covered }\end{array}$ & Strength & Weakness & $\begin{array}{l}\text { Availablal } \\
\text { ity in } \\
\text { Simapro } \\
8.5 \text {. }\end{array}$ & $\begin{array}{l}\text { Pertinence } \\
\text { for our } \\
\text { study }\end{array}$ \\
\hline $\begin{array}{l}\text { Ecological } \\
\text { Scarcity } \\
2013 \\
\text { (endpoint) }\end{array}$ & $2017^{3}$ & $\begin{array}{l}\text { Around } \\
400^{2}\end{array}$ & $\begin{array}{l}\text { Valid for mid- } \\
\text { Europe }^{1}\end{array}$ & $\begin{array}{l}\text { Does not } \\
\text { consider land- } \\
\text { transformation } \\
\text { impacts }^{2}\end{array}$ & $\begin{array}{l}\text { Yes } \\
\text { v.1.05. }\end{array}$ & -- \\
\hline $\begin{array}{l}\text { Eco- } \\
\text { indicator }\end{array}$ & $2013^{3}$ & $\begin{array}{l}\text { Around } \\
400^{2}\end{array}$ & $\begin{array}{l}\text { Valid for mid- } \\
\text { Europe }^{1} \text {, }\end{array}$ & $\begin{array}{l}\text { Valid for } \\
\text { vascular plants }\end{array}$ & $\begin{array}{l}\text { Yes. } \\
\text { v.2.10. }\end{array}$ & + \\
\hline
\end{tabular}




\begin{tabular}{|c|c|c|c|c|c|c|}
\hline $\begin{array}{l}99 \\
\text { (endpoint) }\end{array}$ & & & $\begin{array}{l}\text { recommended by } \\
\text { EC in the specific } \\
\text { context of } \\
\text { buildings }^{1,7}\end{array}$ & $\begin{array}{l}\text { only }^{2} \text {, based on } \\
\text { old data }^{1}\end{array}$ & & \\
\hline $\begin{array}{l}\text { EPS } 2000 \\
\text { (endpoint) }\end{array}$ & $2015^{3}$ & $\begin{array}{l}\text { Around } \\
200^{2}\end{array}$ & $\begin{array}{l}\text { Based on the red } \\
\text { list of endangered } \\
\text { species }^{1}\end{array}$ & $\begin{array}{l}\text { Only based on } \\
\text { Swedish data }{ }^{1,2}\end{array}$ & $\begin{array}{l}\text { Yes. } \\
\text { v. } 1.00\end{array}$ & -- \\
\hline $\begin{array}{l}\text { LIME } \\
\text { (endpoint) }\end{array}$ & - & $\begin{array}{l}\text { Around } \\
1000^{2}\end{array}$ & $\begin{array}{l}\text { Impacts are } \\
\text { regionalized }\end{array}$ & $\begin{array}{l}\text { Valid for Japan } \\
\text { only }\end{array}$ & No. & --- \\
\hline $\begin{array}{l}\text { ReCiPe } \\
2016 \\
\text { (endpoint) }\end{array}$ & $2017^{3}$ & $\begin{array}{l}\text { Around } \\
3000^{2}\end{array}$ & $\begin{array}{l}\text { Valid for mid- } \\
\text { Europe }^{1} \\
\text { and recommended } \\
\text { by ILCD as an } \\
\text { interim solution }{ }^{2}\end{array}$ & $\begin{array}{l}\text { Update of } \\
\text { ReCiPe } 2008 \\
\text { (which is widely } \\
\text { applied }^{1} \text { ), but } \\
\text { the } 2016 \\
\text { version is not } \\
\text { widely applied. }\end{array}$ & $\begin{array}{l}\text { Yes } \\
\text { v.1.01. }\end{array}$ & +++ \\
\hline $\begin{array}{l}\text { Impact } \\
\text { World + }\end{array}$ & $2017^{3}$ & $\begin{array}{l}\text { More } \\
\text { than } \\
1500^{2}\end{array}$ & $\begin{array}{l}\text { Impacts are } \\
\text { regionalized, based } \\
\text { on the red list of } \\
\text { endangered } \\
\text { species } 5 \\
\text { Specific } \\
\text { characterization } \\
\text { factors for five } \\
\text { different taxonomic } \\
\text { groups }{ }^{5}\end{array}$ & $\begin{array}{l}\text { Update of the } \\
\text { IMPACT 2002+ } \\
\text { (widely } \\
\text { applied7), } \\
\text { LUCAS, and } \\
\text { EDIP methods } \\
\text { but not widely } \\
\text { applied }\end{array}$ & $\begin{array}{l}\text { Yes. } \\
\text { v.0.04. }\end{array}$ & +++ \\
\hline $\begin{array}{l}\text { LC- } \\
\text { IMPACT } \\
\text { LU }\end{array}$ & - & - & $\begin{array}{l}\text { Impacts are } \\
\text { regionalized. Based } \\
\text { on the red list of } \\
\text { endangered }\end{array}$ & $\begin{array}{l}\text { Very new } \\
\text { method, has } \\
\text { not yet been } \\
\text { widely }\end{array}$ & No & ++ \\
\hline
\end{tabular}




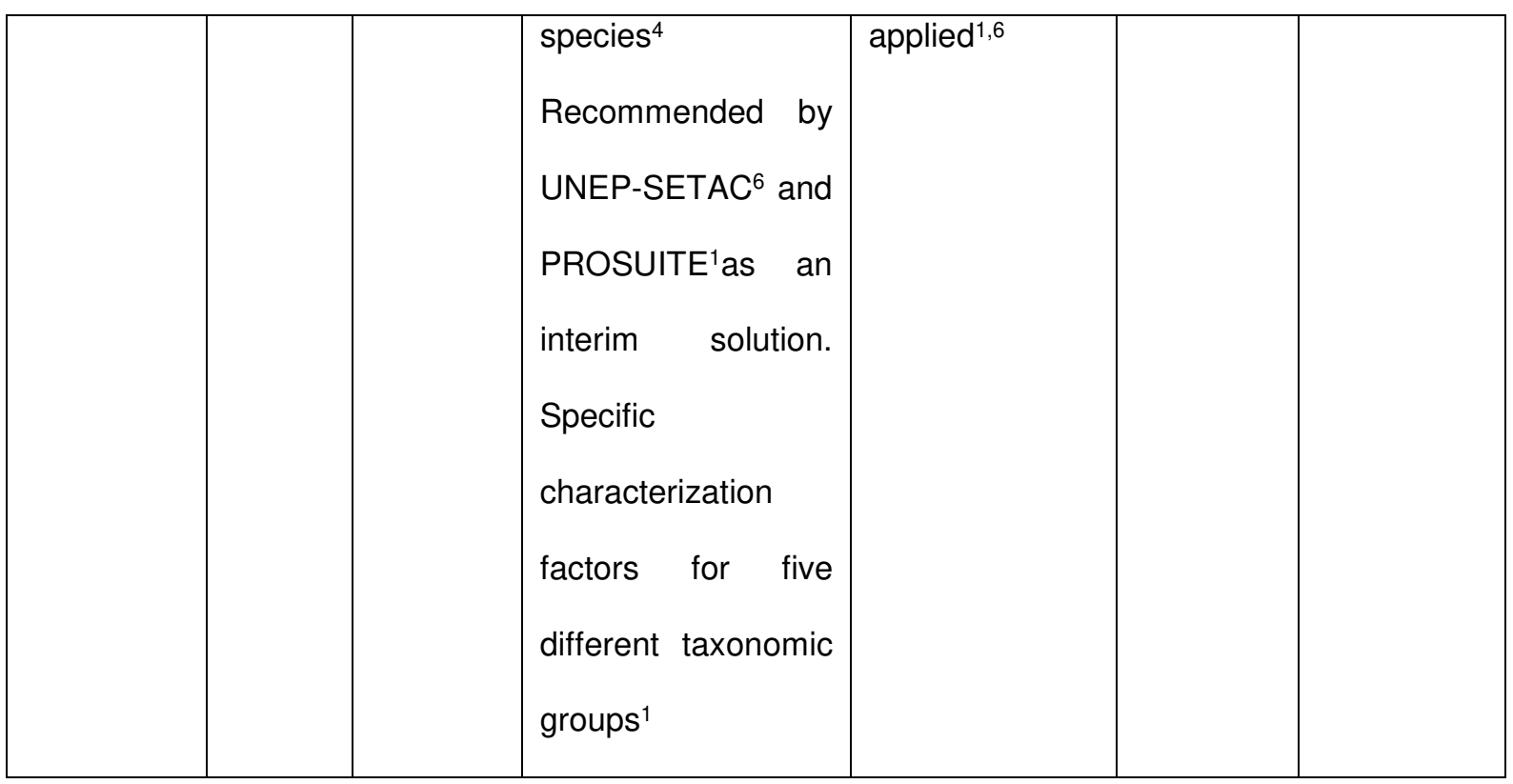

EPS 2000 and LIME methods are excluded as they are valid only in Sweden and Japan respectively.

Ecological Scarcity 2013 is excluded because it does not consider land transformation impacts [68] which are important drivers of the biodiversity loss [8].

Eco-indicators 99 is recommended in the specific context of buildings as it includes land transformation impacts and it takes into account land transformation processes related to mineral extraction and the urban built area [30]. However, this method is based on data from 20 years now [30] and considers only vascular plants [73].

LC-IMPACT seems to be a relevant method to calculate an impact on biodiversity as it is recommended (i.e. by UNEP-SETAC [71] and PROSUITE [30]). However, it is not available on Simapro 8.5.

The relevance of ReCiPe 2016 (v.1.01) and Impact World + (v.0.04) is not yet discussed in the literature because they are new methods. However, they are the updates of respectively ReCiPe 2008 and Impact 2002+. As ReCiPe 2008 was recommended by the ILCD Handbook as an interim solution, its last updated version (ReCiPe 2016) was chosen for this study. Impact World + is the update of Impact 2002 + and was chosen for this study because it is widely applied [72] and because impacts are regionalized (i.e. it takes into account the species specificity at a biome level [70]). 
ReCiPe 2016 and Impact World + are endpoint methodologies. They enable to calculate human health and ecosystems damage. For this study, we chose to focus ourselves only on indicators that express an ecosystems damage.

$\mathrm{ReCiPe} 2016$ methodology is available in three versions considering three different temporal perspectives [32]: 1) Individualist (time horizon of 20 years), 2) Hierarchist (time horizon of 100 years) and 3) Egalitarian (time horizon of 1000 years). It calculates 22 indicators whose 12 are related to ecosystem damage and expressed in "species.yr" unit: global warming for terrestrial ecosystems and freshwater ecosystems, ozone formation, terrestrial acidification, freshwater and marine eutrophication, terrestrial, freshwater and marine ecotoxicity, land use, terrestrial and aquatic water consumption.

Impact World + enable calculate 30 indicators whose 15 are related to an ecosystem damage and expressed in "PDF.m².yr" unit: global warming (short-term and long-term version), marine acidification (short-term and long-term version), land occupation, water use impacts on aquatic ecosystems, water table lowering impacts, thermally polluted water, water stream use and management, terrestrial acidification, aquatic and marine eutrophication, aquatic ecotoxicity (short-term and long-term version), ionizing radiation for aquatic ecosystem. Indicators calculate in a short-term version are considering a 100 years' timehorizon.

ReCiPe 2016 Hierarchist version and Impact World + short-term indicators are applied in this study as a 100 years' time-horizon is the most common policy principles.

\subsection{Results treatments}

ReCiPe 2016 and Impact World + methods express indicator results in 2 different units: respectively "species.yr" and "PDF.m².yr". To compare the two methods, we chose to convert the unit "species.yr" into the unit "PDF.m².yr" by dividing the ReCiPe 2016 results with factors that are specified in the method's report [32]: 1) 1.48E-0.8 for terrestrial species, 2) 7.89E-10 
for freshwater species, 3) 3.46E-12 for marine species. The "PDF.m².yr" unit is retained in this study, mostly because it is the most used and recommended in other studies [30]. The "PDF.m².yr" unit represents the Potentially Disappeared Fraction of species over a given area and a given timespan [74], compared to a natural reference state.

As we decided to focus ourselves on an ecosystem damage assessment analysis, all indicators used are expressed with the same unit ("PDF.m².yr"), it is possible to aggregate them to get a single score by use of weighting factors. According to Recipe 2016 and Impact World + methods, this weighting factor is equal to 1 for each indicator. It means that all indicators have the same importance, for the calculation of the single score.

To obtain the total biodiversity impact of each roof, results from "ex situ" and "in situ" biodiversity impacts are added together. To compare roof systems, we followed the EeBGuide recommendation [75]: to affirm that an option is better than another, there should be an impact difference of about $20 \%$ or more between the two. This enables to consider the uncertainties related to the LCA analysis.

To identify the best option between roof systems, we normalized all the results to the highest impact roof.

\section{Results and interpretation}

\subsection{Total biodiversity impact assessment}

The Life Cycle Impact Assessment for "ex situ" and "in situ" biodiversity is calculated for each roof with a lifespan of 40 years. The addition of the results gives the impact assessment on the total biodiversity. Characterizations results for all indicators are presented in Table 4 for the ReCiPe method and in Table 5 for the Impact World + method.

Table 4: Total biodiversity impacts of conventional and green roofs with the ReCiPe 2016 method

\begin{tabular}{|l|l|l|l|l|}
\hline & Conventional & Extensive & Semi-intensive & Intensive green \\
\hline
\end{tabular}




\begin{tabular}{|c|c|c|c|c|}
\hline & roof (species.yr) & $\begin{array}{l}\text { green roof } \\
\text { (species.yr) }\end{array}$ & $\begin{array}{l}\text { green roof } \\
\text { (species.yr) }\end{array}$ & roof (species.yr) \\
\hline \multicolumn{5}{|c|}{ "Ex situ" biodiversity } \\
\hline $\begin{array}{l}\text { Global warming, } \\
\text { Terrestrial ecosystems }\end{array}$ & $7.22 \mathrm{E}-07$ & $4.25 \mathrm{E}-07$ & $5.50 \mathrm{E}-07$ & 7.19E-07 \\
\hline $\begin{array}{l}\text { Global warming, } \\
\text { Freshwater ecosystems }\end{array}$ & $1.97 \mathrm{E}-11$ & $1.16 \mathrm{E}-11$ & $1.50 \mathrm{E}-11$ & $1.96 \mathrm{E}-11$ \\
\hline $\begin{array}{l}\text { Ozone formation, } \\
\text { Terrestrial ecosystems }\end{array}$ & 8.57E-08 & 4.49E-08 & 5.79E-08 & $7.44 \mathrm{E}-08$ \\
\hline Terrestrial acidification & $2.09 \mathrm{E}-07$ & $1.16 \mathrm{E}-07$ & $1.48 \mathrm{E}-07$ & $2.46 \mathrm{E}-07$ \\
\hline Freshwater eutrophication & $4.01 \mathrm{E}-08$ & $1.83 \mathrm{E}-08$ & $2.24 \mathrm{E}-08$ & $2.84 \mathrm{E}-08$ \\
\hline Marine eutrophication & $7.36 \mathrm{E}-12$ & $3.25 \mathrm{E}-12$ & $5.05 \mathrm{E}-12$ & $8.59 \mathrm{E}-12$ \\
\hline Terrestrial ecotoxicity & $9.42 \mathrm{E}-09$ & 5.31E-09 & 6.88E-09 & $8.78 \mathrm{E}-09$ \\
\hline Freshwater ecotoxicity & 3.69E-09 & $2.22 \mathrm{E}-09$ & 2.85E-09 & 3.34E-09 \\
\hline Marine ecotoxicity & $8.12 \mathrm{E}-10$ & $4.87 \mathrm{E}-10$ & $6.25 \mathrm{E}-10$ & $7.30 \mathrm{E}-10$ \\
\hline Land use & $6.50 \mathrm{E}-08$ & $2.64 \mathrm{E}-08$ & $3.90 \mathrm{E}-08$ & 5.77E-08 \\
\hline $\begin{array}{l}\text { Water consumption, } \\
\text { Terrestrial ecosystem }\end{array}$ & 3.27E-08 & 3.67E-08 & $1.64 \mathrm{E}-07$ & 2.34E-07 \\
\hline $\begin{array}{l}\text { Water consumption, } \\
\text { Aquatic ecosystems }\end{array}$ & $1.47 \mathrm{E}-12$ & $1.64 \mathrm{E}-12$ & 7.33E-12 & $1.05 \mathrm{E}-11$ \\
\hline \multicolumn{5}{|c|}{ "In situ" biodiversity } \\
\hline Land use & $2.59 \mathrm{E}-07$ & $2.59 \mathrm{E}-07$ & $2.59 \mathrm{E}-07$ & $2.59 \mathrm{E}-07$ \\
\hline \multicolumn{5}{|c|}{ Total biodiversity ("ex situ” + “in situ”) } \\
\hline Unique score (species.yr) & $1.43 \mathrm{E}-06$ & 9.34E-07 & $1.25 \mathrm{E}-06$ & $1.63 \mathrm{E}-06$ \\
\hline Unique score (PDF.m².yr) & $3.86 \mathrm{E}+02$ & $2.29 \mathrm{E}+02$ & $2.97 \mathrm{E}+02$ & $3.62 \mathrm{E}+02$ \\
\hline
\end{tabular}

Table 5: Total biodiversity impacts of conventional and green roofs with the Impact World + method

\begin{tabular}{|l|l|l|l|l|}
\hline & $\begin{array}{l}\text { Conventional } \\
\text { roof }\end{array}$ & $\begin{array}{l}\text { Extensive } \\
\text { green roof }\end{array}$ & $\begin{array}{l}\text { Semi-intensive } \\
\text { green roof }\end{array}$ & $\begin{array}{l}\text { Intensive green } \\
\text { roof (PDF.m².yr) }\end{array}$ \\
\hline
\end{tabular}




\begin{tabular}{|c|c|c|c|c|}
\hline & (PDF.m².yr) & (PDF.m².yr) & (PDF.m².yr) & \\
\hline \multicolumn{5}{|c|}{ "Ex situ" biodiversity } \\
\hline $\begin{array}{l}\text { Global warming. short-term. } \\
\text { Ecosystem }\end{array}$ & $4.68 \mathrm{E}+01$ & $2.61 \mathrm{E}+01$ & $3.35 \mathrm{E}+01$ & $4.86 \mathrm{E}+01$ \\
\hline $\begin{array}{l}\text { Marine acidification. short- } \\
\text { term }\end{array}$ & $3.87 \mathrm{E}+00$ & $2.07 \mathrm{E}+00$ & $2.63 \mathrm{E}+00$ & $2.49 E-02$ \\
\hline $\begin{array}{l}\text { Land } \quad \text { occupation. } \\
\text { biodiversity }\end{array}$ & $5.62 \mathrm{E}+00$ & $2.52 \mathrm{E}+00$ & $3.36 \mathrm{E}+00$ & $5.03 E+00$ \\
\hline $\begin{array}{l}\text { Water use impacts. aquatic } \\
\text { ecosystems }\end{array}$ & $0.00 \mathrm{E}+00$ & 3.10E-05 & 4.65E-05 & $1.66 \mathrm{E}+01$ \\
\hline $\begin{array}{l}\text { Water table lowering } \\
\text { impacts }\end{array}$ & 8.58E-03 & 5.81E-03 & 9.02E-02 & $3.60 \mathrm{E}+01$ \\
\hline Thermally polluted water & $0.00 \mathrm{E}+00$ & $0.00 \mathrm{E}+00$ & $0.00 \mathrm{E}+00$ & $2.48 \mathrm{E}+00$ \\
\hline $\begin{array}{l}\text { Water stream use and } \\
\text { management }\end{array}$ & $0.00 \mathrm{E}+00$ & 4.33E-03 & 6.49E-03 & 5.93E-01 \\
\hline Terrestrial acidification & $8.02 \mathrm{E}+00$ & $3.89 \mathrm{E}+00$ & $4.95 \mathrm{E}+00$ & $4.23 \mathrm{E}+00$ \\
\hline Aquatic eutrophication & 8.93E-01 & $3.83 E-01$ & $5.17 \mathrm{E}-01$ & $2.11 \mathrm{E}+02$ \\
\hline Marine eutrophication & $2.12 \mathrm{E}-01$ & $1.65 \mathrm{E}-01$ & $2.08 \mathrm{E}-01$ & $3.90 \mathrm{E}+00$ \\
\hline $\begin{array}{l}\text { Aquatic ecotoxicity. short- } \\
\text { term }\end{array}$ & $3.51 E-01$ & 4.16E-01 & $6.21 \mathrm{E}-01$ & $1.58 \mathrm{E}+01$ \\
\hline $\begin{array}{l}\text { lonizing radiation. aquatic } \\
\text { ecosystem }\end{array}$ & $1.90 \mathrm{E}-07$ & $9.27 E-08$ & $1.26 \mathrm{E}-07$ & 1.33E-02 \\
\hline \multicolumn{5}{|c|}{ "In situ" biodiversity } \\
\hline Land use & $1.76 \mathrm{E}+01$ & $1.76 \mathrm{E}+01$ & $1.76 \mathrm{E}+01$ & $1.76 \mathrm{E}+01$ \\
\hline \multicolumn{5}{|c|}{ Total biodiversity ("ex situ” + "in situ”) } \\
\hline Unique score (PDF.m².yr) & $8.33 \mathrm{E}+01$ & $5.32 \mathrm{E}+01$ & $6.34 \mathrm{E}+01$ & $7.91 \mathrm{E}+01$ \\
\hline
\end{tabular}

The unique score analysis shows that even if absolute values are not similar between the two methods, the trend is the same: the conventional roof has the highest impact (386 
PDF.m².yr for ReCiPe 2016 and 83 PDF.m².yr for Impact World +). Then comes the intensive green roof (362 and 79 PDF.m².yr), the semi-intensive green roof (297 and 63 PDF.m².yr) and the extensive green roof (229 and 53 PDF.m².yr).

To identify the gap between the studied systems, results were normalized to the conventional roof, that has the strongest impacts as shown in Figure 3.

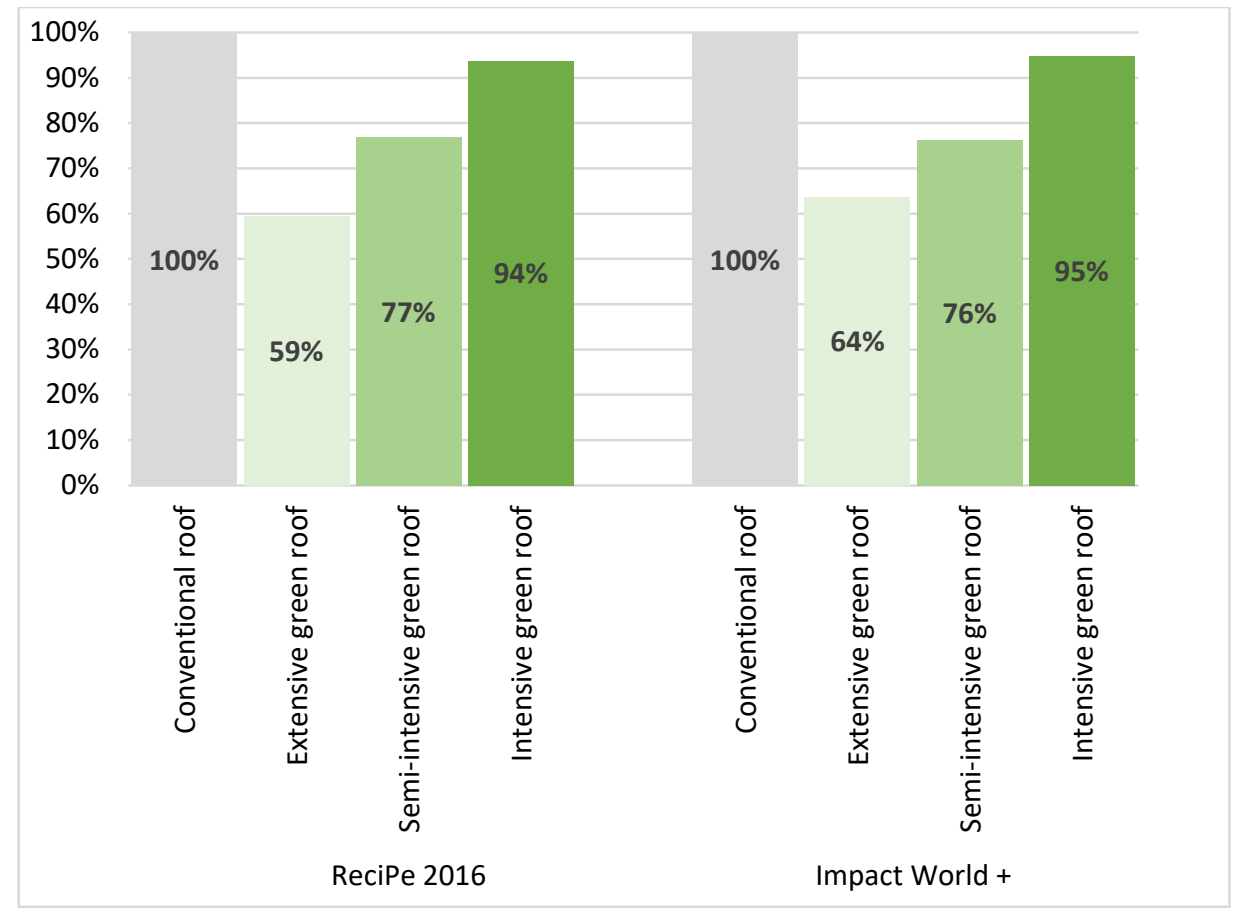

Figure 3: Relatives performances of the roofs systems, in terms of biodiversity impacts with ReCiPe 2016 and Impact World + methods.

The gap between the conventional roof and the extensive and semi-intensive green roofs is higher than 20\%: respectively $41 \%$ and $23 \%$ for the $\operatorname{ReCiPe} 2016$ method, and $36 \%$ and 24\% for the Impact World + method. The gap between the conventional and the intensive roof is lower than 20\%: 6\% and 5\% for ReCiPe 2016 and Impact World +. According to ReCiPe 2016 and Impact World + methods, extensive and semi-intensive green roofs cause a lower biodiversity loss than the conventional roof. Conventional roof and intensive green roofs are equivalent in terms of biodiversity loss, it is not possible to conclude.

Following the same logic, we identified the best options between green roofs (normalization to the intensive green roofs). Extensive green roof causes less biodiversity loss than the intensive one: impact difference of 37\% for ReCiPe 2016 and 33\% for Impact World +. 
This is due to the addition of materials requires to build the different green roofs (i.e. resizing of the concrete slab, the substrate and the water retention thickness).

\subsection{Ratio between "ex situ" and "in situ" biodiversity}

In Table 4 and Table 5, one can notice that for "in situ" biodiversity impact, whatever the roof system and whatever the method, the result is the same: 18.PDF.m².yr. ReCiPe 2016 and Impact World + do not differentiate the "in situ" occupation impact between $1 \mathrm{~m}^{2}$ of conventional roof and $1 \mathrm{~m}^{2}$ of green roof, neither the difference of species richness between the three green roofs. However, results concerning the "ex situ" biodiversity are significantly different. For each roof systems studied, Figure 4 shows the proportions of "in situ" and "ex situ" biodiversity affected regarding the total amount of biodiversity loss.

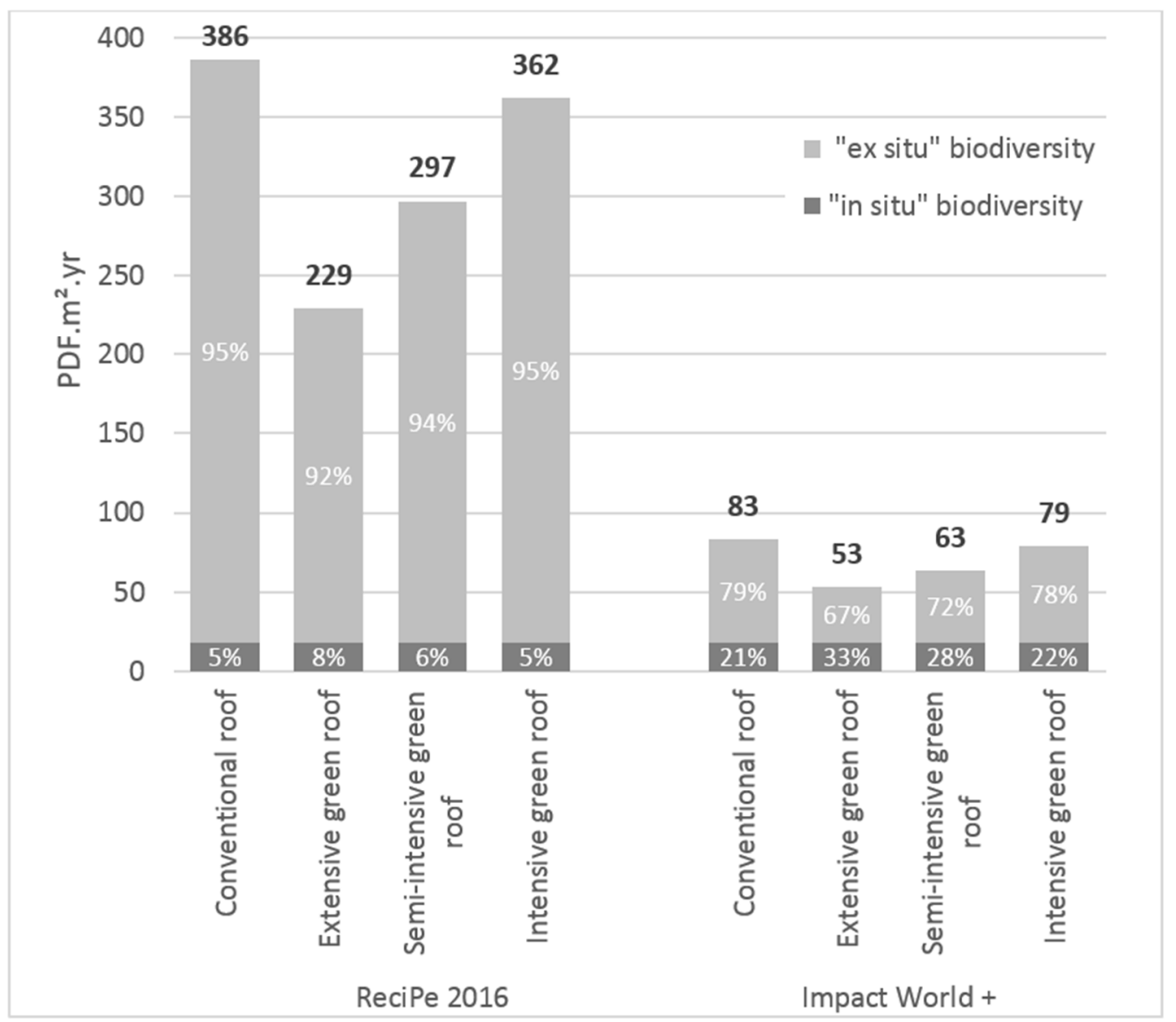

Figure 4: Impact on global biodiversity of roofs according to ReCiPe 2016 and Impact World + methods with details of the impact's contribution of "ex situ" and "in situ" biodiversity. 
For all roof systems and methods applied in this study, the biodiversity "ex situ" is the most affected during the roofs life cycle. Biodiversity "ex situ" represents at least $67 \%$ of the total biodiversity impacts. On average, according to ReCiPe 2016 and Impact World + results, "ex situ" biodiversity is 10 times more impacted than the "in situ" biodiversity. To preserve biodiversity, actions should be taken not only on the construction site (as it is often the case) but also - and maybe as a priority- in the other stages of the construction process (i.e. product and end of life stages).

\subsection{Contribution of each green roof layers to the total "ex situ" biodiversity loss: vegetation layer impact is significant}

To determine the contribution of each layer to the total "ex situ" biodiversity impact of the three green roofs, we considered all the contributions that are linked to this layer. For example, for the vegetation layer, we considered: plants LCI (i.e. Centaurea montana, shrubs, sedum or grass), their transportation to the construction site, their different needs (fertilization, irrigation, pruning), the transportation to the compost area and the composting process. Contributions depend on the green roof type and of the calculation method.

Results are shown in Figure 5 and Figure 6. 


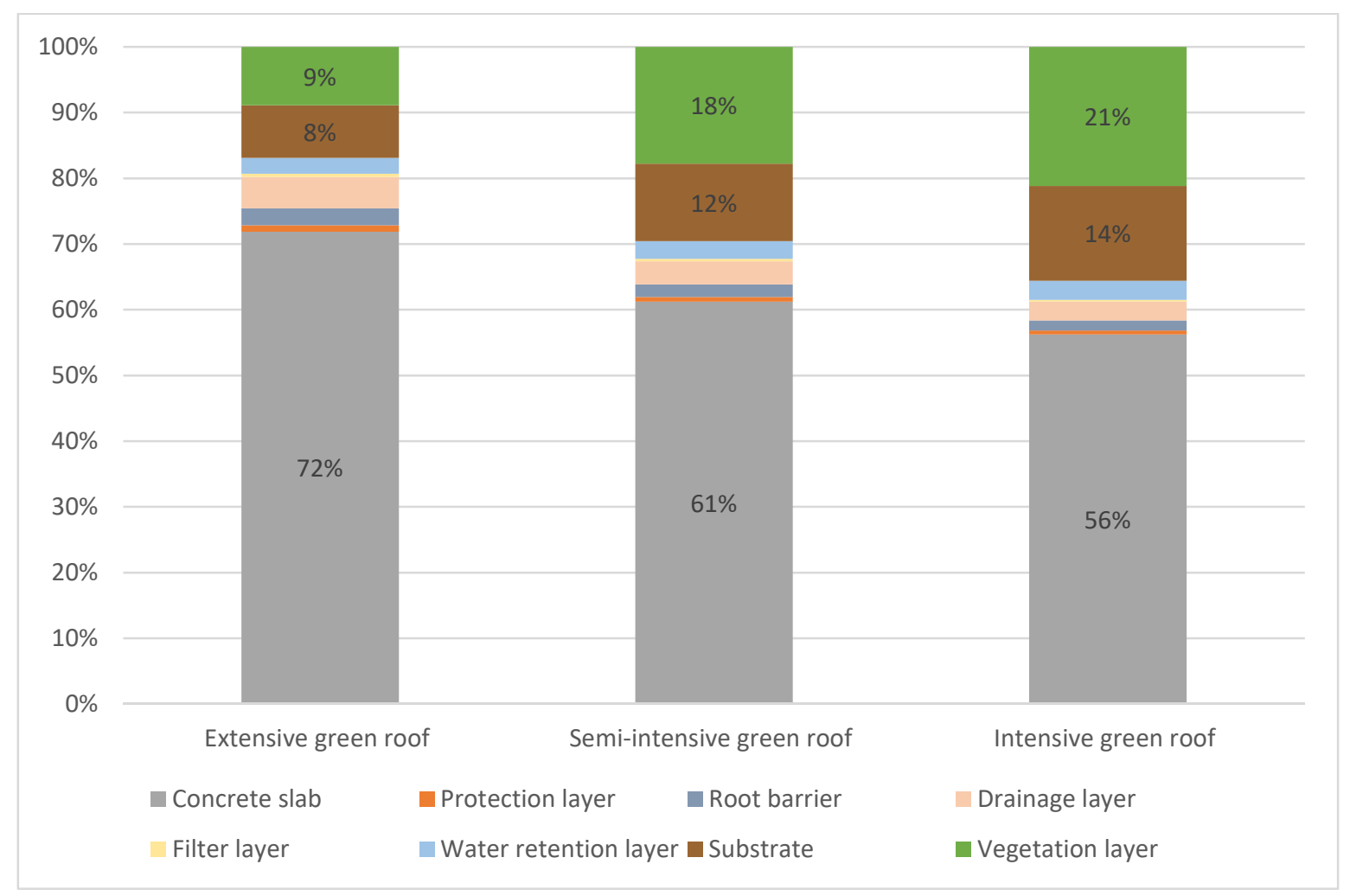

Figure 5: Contribution of the layers to the total impact (i.e. unique score in "PDF.m².yr") of the green roofs with ReCiPe 2016 method

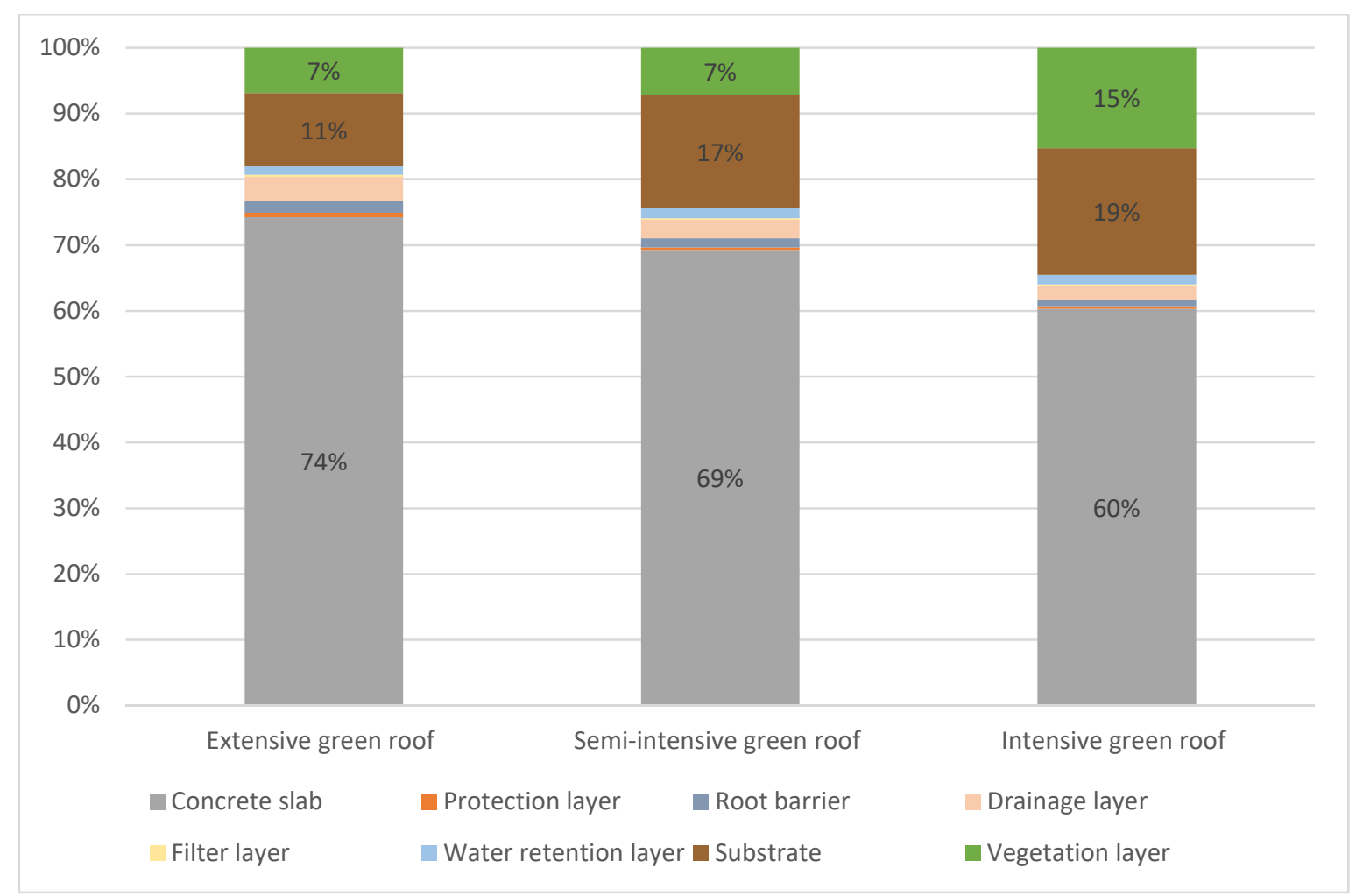

Figure 6: Contribution of the layers to the total impact (i.e. unique score in "PDF.m².yr") of the green roofs with Impact World + method 
The absolute values of the two methods are different. Nevertheless, they are showing the same trend: concrete slab, substrate and vegetation are responsible for approximately $90 \%$ of the total biodiversity loss.

For all cases, it appears that it is the concrete slab layer that has the highest impact (from $56 \%$ to $74 \%$ of the overall impact). To model the $1 \mathrm{~kg}$ of concrete slab, we used $0.98 \mathrm{~kg}$ of concrete (i.e. "Concrete, 35MPa $\{$ GLO\}| market for | Cut-off. U) and $0.01 \mathrm{~kg}$ of steel frame (i.e. "Reinforcing steel $\{$ GLO\}| market for | Cut-off, U"). The analysis of the concrete slab (with ReCiPe 2016 and Impact World + methods for ecosystem damage) shows that the concrete is the material that impacts the most the biodiversity and especially the electricity consumption involved in the clinker production and the heat necessary to create the lime, which is its main component.

For ReCiPe 2016 methodology, the second most contributing layer to biodiversity loss is the vegetation layer. Vegetation represents less than $0.8 \%$ of the overall green roofs weight, but it contributes from $9 \%$ to $21 \%$ of the overall impact.

For Impact World + methodology, the second layer that affects the most biodiversity loss is the substrate layer (from $11 \%$ to $19 \%$ of the overall impact). The third is the vegetation layer (from 7 to $15 \%$ ).

To model the substrate, we used expended clay ("Expanded clay $\{$ GLO\}| market for | Cut-off, U”), compost ("Compost, at plant/FR U" from AGRIBALYSE) and crushed bricks. For them, as Chenani et al. 2015 [51], we considered that bricks are construction wastes and thus we did not count them as raw materials. However, processes to crush the bricks: "Rock crushing \{GLO\}| market for | Cut-off, U" and "Electricity, medium voltage $\{F R\} \mid$ market for | Cut-off, U" was considered. The analysis of the substrate layer shows that expended clay is the material that causes the most impact, and particularly the heat (from hard coal) necessary for its production. 
To model the vegetation layer, we used the urban plant's data we have created. According to the applied methods, the more the species diversity increase on a green roof, the more the "ex situ" biodiversity is impacted. Indeed, semi-intensive and intensive green roofs (i.e. herbaceous and shrubs) have a higher impact on "in situ" biodiversity than extensive green roof (i.e. sedums). This impact's difference is explained by the additional materials and plants cares necessary to make the intensive green roof viable (e.g. semi-intensive and intensive green roofs are fertilized and irrigated, the extensive green roof is not). It can also be explained by the types of plants planted on green roofs. Before their plantation, sedums require fewer cares (i.e. water, fertilizers,) and less cultivation time than shrubs (i.e. respectively 5 months and 8 months).

Many studies on green roofs tend to consider only the cares of the plants, without considering plants culture (i.e. in a plants nursery), transports and end of life processes. These results show that, when studying green roofs, it is essential to model this layer with as much precision as the other layers.

\section{Discussion}

\subsection{Comparison between ReCiPe 2016 and Impact World + results}

\subsubsection{Results on the "ex situ" biodiversity}

The "PDF.m².yr" unit has been chose for the result analysis. If the ReCiPe 2016 unit was chosen ("species.yr"), the conclusion about roof systems impacts would have been the same.

In this study, the two methods show the same trend but the absolute values are very different. There a factor of 5 between the two methods results (i.e. for the intensive green roof, ReCiPe 2016 calculate a biodiversity loss of 344 PDF.m².yr and Impact World + 61 PDF.m².yr.

This difference can be explained by four main reasons: 1) calculated indicators are not the same, 2) the numbers of substances covered is higher for ReCiPe than for Impact World + (around respectively 3000 and 1500 [68], 3) numerical models to calculate indicators are 
different, and thus, substance's characterization factors are different too, 4) the uncertainties links to the marine ecotoxicity indicator calculated in $\mathrm{ReCiPe} 2016$.

ReCiPe LCA methodology is a fusion of CML methodology for the midpoint indicators and Ecoindicator 99 for the endpoint indicators. The calculation of the marine ecotoxicity indicator reveals significant problems related to the time a substance is present in the marine ecosystem and missing data for normalization [76]. If the marine ecotoxicity indicator is not taken into account in this study, the factor between ReCiPe 2016 and Impact World + results goes from 5 to 2 and can be explained by the fact that ReCiPe 2016 consider two times more substances than Impact World + .

\subsubsection{Results on the "in situ" biodiversity}

For the "in situ" biodiversity impact assessment, ReCiPe 2016 and Impact World + give a similar result: 18 PDF.m².yr. This is explained by the fact that even if ReCiPe 2016 proposes different types of urban occupation (e.g. continuous built, discontinuous built...), characterization factors are equal for all of them (i.e. 4.38E-01 PDF.m².yr). Also, this value is similar to the one used to characterize the urban discontinuously built occupation type in Impact World + (i.e. 4.40E-01 PDF.m².yr).

If LCA methods enable to well differentiate forest land from, agriculture and artificial one, they are not precise enough. Indeed, the level of details for artificial lands is not sufficient to discern an urban green area from an urban built area so that a conventional roof as the same "in situ" impact than a green roof. This is relevant of two LCA limitations for biodiversity assessment: 1) methods are not specific enough and 2) it doesn't take into account the plants diversity brings by the vegetation layer as a gain of biodiversity.

There is still some way to go to refine the level of detail of land use characterization.

\subsection{Comparison between "in situ" LCA results and ecological expertise}


This study shows that according to a LCA approach and among the four roof systems, the extensive green roof has the lowest impact on the biodiversity loss (part 3.1.3). The intensive green roof has a higher impact on biodiversity than extensive and semi-intensive ones. Also, when the diversity in plants species increases, the impact on "in situ" biodiversity is unchanged (part 3.1.2). Extensive, semi-intensive and intensive green roofs have thus the same impact on the "in situ" biodiversity.

These results are in contradiction with the ecological expertise which promotes intensive green roof to enhance the biodiversity. Ecological expertise is often used as a decision tool for land use planning. It consists of performing a state of a space by naturalistic inventories before and after a space perturbation, to quantify the impacts on biodiversity. Ecological expertise shows that green roof plants species diversity improves the specific richness $[77,78]$ and the ecosystem multifunctionality [79] of green roofs.

The contradiction between LCA and ecological expertise comes from two main reasons. First, ecological expertise does not consider the "ex situ" biodiversity. The attention is generally focused only on local impacts and "in situ" biodiversity that is not the most affected by roof systems when considering the overall biodiversity. The second reason is that even if the LCA methods used for this study (ReCiPe 2016 and Impact World +) consider "in situ" and "ex situ" biodiversity, they do not consider the "in situ" biodiversity gains due to the vegetation layer itself (sedum, herbaceous and shrubs...). They also do not include beneficial impacts related to green roofs, as for example, the potential habitats that they are recreating and their abilities to welcome species. LCA methods are calculating only negative impacts.

Even if LCA methodology is not complete to enable a complete biodiversity loss assessment and is dependent on the used data, ecological expertise neither. This can conduce to divergent recommendations. Indeed, during a conception stage, ecological experts tend to recommend concrete structures to increase the system lift and make possible intensive green roof installation (that is preferable for the "in situ" biodiversity). But, with a LCA point of 
view and according to the data used in this study to model green roofs, concrete is the most contributor to the biodiversity loss. Complementary studies need to be conducted to compare different buildings' structures (steel, wood...) to strike a balance between used material, lift capacity and biodiversity management.

\subsection{LCA limits to assess biodiversity impacts}

As said before, impact biodiversity assessment is a crucial issue but difficult to achieve due to its complexity. For an appropriate assessment the methodology must consider:

- All pressures on biodiversity: habitat change, invasive species, over-exploitation of resources, pollution, and climate change

- Local and global impacts (i.e. "in situ" and "ex situ" biodiversity)

- Local territories specificities

- Negative and positive impacts (i.e. ecosystemic services)

The methodology also must be comprehensible and reproducible [36].

This work reveals that the LCA approach enables to consider local and global impacts and that LCA is a comprehensible and reproducible methodology. But, LCA approach is not considering all the pressures affecting biodiversity. Indeed, invasive species and physical pollutions (i.e. noise and light pollution) are not converted into indicators by the methods. Over-exploitation of resources is partially counted through water consumption. Global warming and land use are the most accomplished indicators as they are the main drivers of the biodiversity loss $[8,14,73]$.

However, the LCA methodological framework calculate impacts that are "generic in space, summed across time horizons, strongly linked to a functional unit, and free of interactions between impact pathways" [37]. These restrictions start to be addressed by recent LCA research [16]. For example, the land use indicator set up by Chaudhary et al. studies $[69,80]$ takes into account 5 taxonomic groups (i.e. mammals, birds, reptiles, amphibians, and vascular plants), six land use types (i.e. intensive forestry, extensive forestry, annual crops, permanent crops, pasture, and urban) and 804 terrestrial ecoregions to distinct species 
communities. However, to assess a construction project that takes places in an urban area, the actual level of detail of the land use characterization is not sufficient. The consideration of local specificities is well explored for a large spatial scale, but needs to be improved for a smaller one.

\section{Conclusion}

LCA is a relevant methodology to assess biodiversity. In a French context, it is also a pertinent approach to integrate biodiversity in a future regulation as LCA is the selected methodology to assess embedded and operational environment impacts (i.e. energy and CO2 emissions) into the future building regulation. Even if LCA methods to assess biodiversity are criticized because of their lack of maturity, recent research seems to start to address LCA methods limitation. Therefore, we tested two recent LCA methods (i.e. ReCiPe 2016 and Impact World +) on roof systems to discuss their relevance to biodiversity evaluation.

Even if the impacts absolute values obtained with the two methods are different, they show the same trend: 1) extensive green roof causes a lower biodiversity loss than conventional roof and intensive green roof, 2) "ex situ" biodiversity is more exposed to impacts than "in situ" biodiversity, 3) the contribution of the vegetation layer is significant, it has to be modeled properly for an LCA analysis, and thus, LCA database needs to be enhanced with urban plants data, 4) concrete is the material that has the highest impact on biodiversity loss.

The methods analysis shows that ReCiPe 2016 and Impact World + are one of the most complete LCA methods, even if 1) they do not meet all the criteria for a complete biodiversity assessment, 2) they lack of precision to assess "in situ" biodiversity, and 3) they do not catch all the ecosystemic services green roofs can offer. Despite those limitations, LCA methods are still powerful decision's tool for public policies. In this study for example, with a biodiversity point of view decision would tend to choose the extensive green roof as it causes the least loss of biodiversity. 
As explain by Brachet et al. 2017 during the European Conference on Biodiversity and Climate Change in 2017 (ECBCC) [81], to enhance biodiversity LCA methods and reinforce their abilities to assist in decision making, a hybrid methodology coupling LCA, with ecological and buildings expertises approaches seems to be relevant. These complementary approaches can capture "in situ" and "ex situ" biodiversity that are affected among the value chain of a product or system, the local specificities of territories, the five pressures on biodiversity and also negative and positive impacts that a product/system can provide. Positives impacts will be relevant at a building scale (energy gain, water retention, depollution...). It could constitute a robust decision tool for local policies choices.

\section{Acknowledgments}

This work was supported by the Planning and Development Authorities of Marne-la-Vallée and the Scientific and Technical Center for Building.

We thank Mickaël OLMOS and the 2 nurseries "Jardin des Alpes" (nursery A) -J. DENNIEL, C. MARTIN, D. DIETSCHY- and "Damien VIVIER Pépinières" (nursery B) -D. VIVIER - for allowing us to create new data about the Life Cycle Inventory of urban plants.

We thank the French's green roofs professionals for sharing with us their information about the plant's care (P. PEIGER, F. MAYRAND, A. FEVRIER, R. LAME and T. MULLER.) We thank Charlotte HESLOUIN, Charlène FERIAU and Jacques CHEVALIER for the reading of this article. 


\section{References}

[1] A.D. Barnosky, N. Matzke, S. Tomiya, G.O.U. Wogan, B. Swartz, T.B. Quental, C. Marshall, J.L. McGuire, E.L. Lindsey, K.C. Maguire, B. Mersey, E.A. Ferrer, Has the Earth's sixth mass extinction already arrived?, Nature. 471 (2011) 51-57. doi:10.1038/nature09678.

[2] G. Ceballos, P.R. Ehrlich, R. Dirzo, Biological annihilation via the ongoing sixth mass extinction signaled by vertebrate population losses and declines, Proc. Natl. Acad. Sci. (2017) 201704949. doi:10.1073/pnas.1704949114.

[3] IUCN, IUCN Red List of Threatened Species., (2016).

[4] C.A. Hallmann, M. SORG, E. JONGEJANS, H. SIEPEL, N. Hofland, H. Schwan, W. Stenmans, A. Müller, H. Sumser, T. Hörren, D. Goulson, H. De Kroon, More than 75 percent decline over 27 years in total flying insect biomass in protected areas, PLoS One. 12 (2017). doi:10.1371/journal.pone.0185809.

[5] CNRS, Le printemps 2018 s'annonce silencieux dans les campagnes françaises, (2018) 2017-2019.

[6] WWF, Living planet report: risk and resilience in a new era, 2016. doi:978-2-94052940-7.

[7] C. Melhart Slay, A Review of Biodiversity and Land-Use Metrics , Indices , and Methodologies as Related to Agricultural Products, (n.d.).

[8] MEA, Ecosystems and Human Well-being : Synthesis., Island Press, Washington, DC, 2005.

[9] CBD, Quick guides to the Aichi Biodiversity Targets, (2013) 42. http://www.cbd.int/nbsap/training/quick-guides/.

[10] SCBD, Global Biodiversity Outlook 4, 2014. doi:10.2143/KAR.25.0.504988.

[11] G. Ceballos, P.R. Ehrlich, A.D. Barnosky, A. García, R.M. Pringle, T.M. Palmer, Accelerated modern human-induced species losses: Entering the sixth mass extinction, Sci. Adv. 1 (2015) e1400253-e1400253. doi:10.1126/sciadv.1400253.

[12] M. Lenzen, D. Moran, K. Kanemoto, B. Foran, L. Lobefaro, a. Geschke, International trade drives biodiversity threats in developing nations, Nature. 486 (2012) 109-112. doi:10.1038/nature11145.

[13] D. Moran, K. Kanemoto, Identifying the Species Threat Hotspots from Global Supply Chains, Nat. Ecol. Evol. 6 (2017) 1-13. doi:10.1101/076869.

[14] A. Chaudhary, F. Verones, L. De Baan, S. Hellweg, Quantifying Land Use Impacts on Biodiversity: Combining Species-Area Models and Vulnerability Indicators, Environ. Sci. Technol. 49 (2015) 9987-9995. doi:10.1021/acs.est.5b02507.

[15] TEEB, The Economics of Ecosystems and Biodiversity: Ecological and Economic Foundations, (2010) 1-15.

[16] J.P. Lindner, B. Niblick, U. Eberle, U. Bos, E. Schmincke, S. Schwarz, R. Luick, M. Blumberg, A. Urbanek, Proposal of a unified biodiversity impact assessment method, 9th Int. Conf. LCA Food. (2014) 6-11. 
[17] L. De Baan, M. Curran, C. Rondinini, P. Visconti, S. Hellweg, T. Koellner, Highresolution assessment of land use impacts on biodiversity in life cycle assessment using species habitat suitability models, Environ. Sci. Technol. 49 (2015) 2237-2244. doi:10.1021/es504380t.

[18] P. Larrey-Lassalle, Development of regional indexes for habitat fragmentation impacts on biodiversity and integration into environmental assessments, 2017.

[19] E. Lindeijer, M. van Kampen, P. Fraanje, H. van Dobben, G.J. Nabuurs, E. Schouwenberg, D. Prins, N. Dankers, M. Leopold, Biodiversity and Life Support Indicators for Land Use Impacts in Lca, 1998/07 (1998).

[20] J.S. Woods, M. Damiani, P. Fantke, A.D. Henderson, J.M. Johnston, J. Bare, S. Sala, D. Maia de Souza, S. Pfister, L. Posthuma, R.K. Rosenbaum, F. Verones, Ecosystem quality in LCIA: status quo, harmonization, and suggestions for the way forward, Int. J. Life Cycle Assess. (2017) 1-12. doi:10.1007/s11367-017-1422-8.

[21] COMMUNITIES COMMISSION OF THE EUROPEAN, COMMUNICATION FROM THE COMMISSION TO THE COUNCIL AND THE EUROPEAN PARLIAMENT, (2003).

[22] AFNOR, NF EN ISO 14040 - Management environnemental - Analyse du cycle de vie - Principes et cadre, 2006.

[23] AFNOR, NF EN ISO 14044 - Management environnemental - Analyse du cycle de vie - Exigences et lignes directrices, 2006.

[24] M.W. Strohbach, E. Arnold, D. Haase, The carbon footprint of urban green space-A life cycle approach, Landsc. Urban Plan. 104 (2012) 220-229. doi:10.1016/j.landurbplan.2011.10.013.

[25] E. Egorova, H. Perry, L. Smythe, R. Song, S. Sorensen, F. Advisor, R. Geyer, Incorporating Land Use Impacts on Biodiversity into Life Cycle Assessment for the Apparel Industry, (2014).

[26] S. Hellweg, L.M.I. Canals, Emerging approaches, challenges and opportunities in life cycle assessment, Science (80-. ). $344 \quad$ (2014) 1109-1113. doi:10.1126/science.1248361.

[27] AFNOR, NF EN 15804 - Contribution des ouvrages de construction au développement durable - Déclarations environnementales sur les produits - Règles régissant les catégories de produits de construction, (2016).

[28] AFNOR, NF EN 15978 - Contribution des ouvrages de construction au développement durable - Évaluation de la performance environnementale des bâtiments - Méthode de calcul, (2012).

[29] K. Allacker, D. De Lathauwer, W. Debacker, W.C. Lam, K. Boonen, WHICH ADDITIONAL IMPACT CATEGORIES ARE READY FOR UPTAKE IN THE CEN STANDARDS EN 15804 AND EN 15978? EVALUATION FRAMEWORK AND INTERMEDIATE RESULTS, Sustain. Built Environ. Reg. Conf. Zurich 2016. (2016) 234-239. doi:10.3218/3774-6.

[30] CEN, CEN/TC 350 Evaluation of the possibility of adding environmental impact categories and related indicators and calculation methods for the assessment of the environmental performance of buildings pour avis, (2016). 
[31] M. Goedkoop, R. Spriensma, The Eco-indicator 99 - A damage oriented method for Life Cycle Impact Assessment, Assessment. (2001) 144. doi:10.1007/BF02979347.

[32] RIVM, ReCiPe 2016: A harmonized life cycle impact assessment method at midpoint and enpoint level - Report 1 : characterization, Natl. Inst. Public Heal. Environ. (2016) 194. doi:10.1007/s11367-016-1246-y.

[33] O. Jolliet, M. Margni, R. Charles, S. Humbert, J. Payet, G. Rebitzer, R. Rosenbaum, IMPACT 2002+: A New Life Cycle Impact Assessment Methodology, Int. J. Life Cycle Assess. 8 (2003) 324-330. doi:10.1007/BF02978505.

[34] P. Fantke, M. Bijster, C. Guignard, M. Hauschild, M. Huijbregts, O. Jolliet, A. Kounina, V. Magaud, M. Margni, T. McKone, L. Posthuma, R.K. Rosenbaum, D. van de Meent, R. van Zelm, 2, USEtox® 2.0, Documentation version 1, 2017. doi:10.11581/DTU:00000011.

[35] F. Verones, S. Hellweg, L.B. Azevedo, A. Laurent, C.L. Mutel, S. Pfister, LC-Impact, (n.d.) 1-143.

[36] D.M. Souza, R.F.M. Teixeira, O.P. Ostermann, Assessing biodiversity loss due to land use with Life Cycle Assessment: Are we there yet?, Glob. Chang. Biol. 21 (2015) 3247. doi:10.1111/gcb.12709.

[37] M. Curran, L. De Baan, A.M. De Schryver, R. Van Zelm, S. Hellweg, T. Koellner, G. Sonnemann, M.A.J. Huijbregts, Toward meaningful end points of biodiversity in life cycle assessment, Environ. Sci. Technol. 45 (2011) 70-79. doi:10.1021/es101444k.

[38] F. Danic, S. Lepochat, B. Lévêque, L. Moniot, G. Neveux, Comment utiliser les flux, indicateurs et méthodes ACV existants pour traiter l'impact sur la biodiversité, SCORELCA. 33 (2014).

[39] Greater London Authority, Living Roofs and Walls - Technical Report: Supporting London Plan Policy, Gt. London Auth. (2008) 58. https://www.london.gov.uk/sites/default/files/living-roofs.pdf.

[40] M. Shafique, R. Kim, M. Rafiq, Green roof benefits, opportunities and challenges - A review, Renew. Sustain. Energy Rev. 90 (2018) 757-773. doi:10.1016/j.rser.2018.04.006.

[41] F. Bianchini, K. Hewage, How "green" are the green roofs? Lifecycle analysis of green roof materials, Build. Environ. 48 (2012) 57-65. doi:10.1016/j.buildenv.2011.08.019.

[42] I. Jaffal, S.E. Ouldboukhitine, R. Belarbi, A comprehensive study of the impact of green roofs on building energy performance, Renew. Energy. 43 (2012) 157-164. doi:10.1016/j.renene.2011.12.004.

[43] H.F. Castleton, V. Stovin, S.B.M. Beck, J.B. Davison, Green roofs; Building energy savings and the potential for retrofit, Energy Build. 42 (2010) 1582-1591. doi:10.1016/j.enbuild.2010.05.004.

[44] S. Saiz, C. Kennedy, B. Bass, K. Pressnail, Comparative life cycle assessment of standard and green roofs, Environ. Sci. Technol. 40 (2006) 4312-4316. doi:10.1021/es0517522.

[45] I. Teotónio, C.M. Silva, C.O. Cruz, Eco-solutions for urban environments regeneration: The economic value of green roofs, J. Clean. Prod. 199 (2018) 121-135. 
doi:10.1016/j.jclepro.2018.07.084.

[46] T. Carter, A. Keeler, Life-cycle cost-benefit analysis of extensive vegetated roof systems, J. Environ. Manage. 87 (2008) 350-363. doi:10.1016/j.jenvman.2007.01.024.

[47] P. CLERGEAU, Verdir la ville ou favoriser la biodiversité ?, Ecologik. 54 (2017) 106107.

[48] LEGIFRANCE, LOI $\mathrm{n}^{\circ}$ 2016-1087 du 8 août 2016 pour la reconquête de la biodiversité, de la nature et des paysages - Article 86, (2016). https://www.legifrance.gouv.fr/affichCodeArticle.do?cidTexte=LEGITEXT00000607407 5\&idArticle=LEGIARTI000033034434\&dateTexte $=$.

[49] LEGIFRANCE, Code de l'urbanisme - Article L111-19, (2017). https://www.legifrance.gouv.fr/affichCodeArticle.do?cidTexte=LEGITEXT00000607407 5\&idArticle $=$ LEGIARTI000033034434\&dateTexte $=$.

[50] C. Lamnatou, D. Chemisana, Evaluation of photovoltaic-green and other roofing systems by means of ReCiPe and multiple life cycle-based environmental indicators, Build. Environ. 93 (2015) 376-384. doi:10.1016/j.buildenv.2015.06.031.

[51] S.B. Chenani, S. Lehvävirta, T. Häkkinen, Life cycle assessment of layers of green roofs, J. Clean. Prod. 90 (2015) 153-162. doi:10.1016/j.jclepro.2014.11.070.

[52] C. Gargari, C. Bibbiani, F. Fantozzi, C.A. Campiotti, Environmental Impact of Green Roofing: The Contribute of a Green Roof to the Sustainable use of Natural Resources in a Life Cycle Approach, Agric. Agric. Sci. Procedia. 8 (2016) 646-656. doi:http://dx.doi.org/10.1016/j.aaspro.2016.02.087.

[53] P. Vacek, K. Struhala, L. Matejka, Life-cycle study on semi intensive green roofs, J. Clean. Prod. 154 (2017) 203-213. doi:10.1016/j.jclepro.2017.03.188.

[54] ECOINVENT, Ecoinvent 3, (2018). https://www.ecoinvent.org/home.html.

[55] SIMAPRO, Agri-footprint, (2014). https://simapro.com/databases/agri-footprint/.

[56] ESU SERVICES, Swiss Input-Output-Database, (2005). http://esuservices.ch/projects/ioa/.

[57] P. Koch, T. Salou, V. Colomb, S. Payen, S. Perret, A. Tailleur, S. Willmann, AGRIBALYSE ® : RAPPORT METHODOLOGIQUE - Version 1.2, (2014) 1-473.

[58] CSTB-FCBA-KARIBATI-TRIBU, PEBIOS: Performance Environnementale des bâtiments BIOsourcés, Res. Proj. Support. by ADEME. (2018).

[59] L. Kosareo, R. Ries, Comparative environmental life cycle assessment of green roofs, Build. Environ. 42 (2006) 2606-2613. doi:10.1016/j.buildenv.2006.06.019.

[60] ADIVET, CSFE, Enveloppe Métalique du Bâtiment, Règles professionnelles pour la conception et la réalisation des terrasses et toitures végétalisées, 2018.

[61] BARENBRUG, Quelle quantité de graines faut-il semer?, (n.d.). http://semergazon.fr/quelle-quantite-de-graines-faut-il-semer/.

[62] BIODIVERSITE \& BATI, GUIDE TECHNIQUE. Fiche 1: Toitures végétalisées: les différents systèmes Techniques, (n.d.). 
[63] S.W. Peck, C. Callaghan, M.E. Kuhn, B. Bass, Greenbacks from green roofs: Forging a new industry in Canada status report on benefits, barriers and opportunities for green roof and vertical garden technology diffusion, Environment. (1999) 78. doi:10.1007/s13398-014-0173-7.2.

[64] C. Van Mechelen, T. Dutoit, M. Hermy, Adapting green roof irrigation practices for a sustainable future: A review, Sustain. Cities Soc. 19 (2015) 74-90. doi:10.1016/j.scs.2015.07.007.

[65] PlasticsEurope, Plastics-the facts 2017, An analysis of European plastics production, demand and waste data; 2017, (2017). doi:10.1016/j.marpolbul.2013.01.015.

[66] UNICEM, Engagement pour la croissance verte relatif à la valorisation et au recyclage des déchets inertes du BTP, (2016) 1-8.

[67] ECOINVENT, Background data for transport, (2013). https://www.ecoinvent.org/support/documents-and-files/documents-and-files.html.

[68] EC-JRC, ILCD Handbook: Analysis of existing Environmental Impact Assessment methodologies for use in Life Cycle Assessment, (2010) 105.

[69] A. Chaudhary, F. Verones, L. de Baan, S. Hellweg, Quantifying Land Use Impacts on Biodiversity: Combining Species - Area Models and Vulnerability Indicators, Environ. Sci. Technol. 49 (2015) 9987-9995. doi:10.1021/acs.est.5b02507.

[70] CIRAIG, DTU, QUANTIS, U. of MICHIGAN, IMPACT WORLD +, (2018). http://www.impactworldplus.org/en/presentation.php.

[71] UNEP/SETAC, Global Guidance for Life Cycle Impact Assessment Indicators, 1 (2016) 166. doi:10.1146/annurev.nutr.22.120501.134539.

[72] K. Allacker, D.M. de Souza, S. Sala, Land use impact assessment in the construction sector: an analysis of LCIA models and case study application, Int. J. Life Cycle Assess. 19 (2014) 1799-1809. doi:10.1007/s11367-014-0781-7.

[73] PreConsultants, Eco-indicator 99 Manual for Designers, Minist. Housing, Spat. Plan. Environ. $\quad(2000) \quad 1-49$. sustainability.com/download/manuals/El99_Manual.pdf.

[74] S. Humbert, A. De Schryver, M. Margni, O. Jolliet, IMPACT 2002 + : User Guide, 2 (2002).

[75] B. Wittstock, J. Gantner, K. Lenz, \& Al, EeBGuide - Part B : BUILDING, 2012.

[76] I. Blom, L. Itard, A. Meijer, LCA-based environmental assessment of the use and maintenance of heating and ventilation systems in Dutch dwellings, Build. Environ. 45 (2010) 2362-2372. doi:10.1016/j.buildenv.2010.04.012.

[77] H. Johan, M. Barra, M. Zucca, Gestion et Protection de la Nature Étude sur la biodiversité des toitures végétalisées en Île-de-France, (2017).

[78] F. Madre, A. Vergnes, N. Machon, P. Clergeau, A comparison of 3 types of green roof as habitats for arthropods, Ecol. Eng. 57 (2013) 109-117. doi:10.1016/j.ecoleng.2013.04.029.

[79] J.T. Lundholm, Green roof plant species diversity improves ecosystem 
multifunctionality, J. Appl. Ecol. 52 (2015) 726-734. doi:10.1111/1365-2664.12425.

[80] A. Chaudhary, T.M. Brooks, Land Use Intensity-specific Global Characterization Factors to Assess Product Biodiversity Footprints, Environ. Sci. Technol. (2018) acs.est.7b05570. doi:10.1021/acs.est.7b05570.

[81] A. Brachet, N. Schiopu, P. Clergeau, Combining ecological and life cycle assessment of urban projects, a way to support biodiversity conservation and climate change reduction, in: Proc. Eur. Conf. "Biodiversity Heal. Face Clim. Chang. - Challenges, Oppor. Evid. Gaps Evid. Gaps,” 2017. 